\title{
THE RESPONSE OF HOUSEHOLD SAVING TO THE LARGE SHOCK OF GERMAN REUNIFICATION
}

\author{
Nicola Fuchs-Schündeln \\ CRR WP 2008-21 \\ Released: November 2008 \\ Date Submitted: October 2008 \\ Center for Retirement Research at Boston College \\ Hovey House \\ 140 Commonwealth Avenue \\ Chestnut Hill, MA 02467 \\ Tel: 617-552-1762 Fax: 617-552-0191
}

The research reported herein was pursuant to a grant from the U.S. Social Security Administration (SSA) funded as part of the Retirement Research Consortium (RRC). The findings and conclusions expressed are solely those of the authors and do not represent the views of SSA, any agency of the Federal Government, the RRC or Boston College.

(C) 2008, by Nicola Fuchs-Schündeln. All rights reserved. Short sections of text, not to exceed two paragraphs, may be quoted without explicit permission provided that full credit, including (C) notice, is given to the source. 


\begin{abstract}
German reunification was a large, unexpected shock for East Germans, with different economic consequences for different birth cohorts. Exploiting German reunification as a natural experiment, I analyze the validity of the life cycle consumption model. In the empirical part, I derive three stylized features concerning the saving behavior of East vs. West Germans in the 1990s: (i) East Germans have higher saving rates than West Germans after reunification, (ii) this East-West gap in saving rates is increasing in the age of the birth cohort, and (iii) for every cohort, this gap is declining over time. The theoretical part investigates whether a comprehensive life cycle model can predict these three features. I find strong evidence in favor of rational, forward looking saving behavior. The precautionary saving motive is essential in replicating the features from the data.
\end{abstract}




\section{Introduction}

German reunification was a large economic shock for East Germans. Natural experiments of this scale have typically been missing for industrialized countries, except for wars. I use the natural experiment of German reunification to gain insights into the validity of the life cycle consumption model, and to analyze the relative importance of different saving motives. The life cycle hypothesis, originally formulated by Modigliani and Brumberg in 1954, is the dominant paradigm in economics for studying consumption and saving behavior. ${ }^{1}$ Under perfect foresight, the life cycle hypothesis, as a special form of Friedman's (1957) permanent income hypothesis, implies that consumption changes should be uncorrelated with expected income changes.

The comovement of consumption and income over the working life has been recognized early on as a challenge for the life cycle hypothesis (Thurow, 1969). Yet, there exist several explanations for this phenomenon that are consistent with rational behavior, most importantly the presence of liquidity constraints, precautionary savings, or changing demographics over the life cycle. ${ }^{2}$ Several studies conclude that these three factors can cause the observed comovement of income and consumption over the working life (see e.g. Attanasio and Weber, 1995, and Attanasio et al., 1999, for demographics; Gourinchas and Parker, 2002, for precautionary savings; and Gross and Souleles, 2002, for evidence of liquidity constraints). ${ }^{3}$ It is difficult to come to a conclusion about the relative importance of different theories in studies that are solely based on the observed comovement phe-

\footnotetext{
${ }^{1}$ There are varying definitions of the life cycle hypothesis. I use the term mainly to emphasize rational behavior, the presence of a retirement period, and a finite lifetime.

${ }^{2}$ Another possible explanation lies in the complementarity of consumption and labor (Heckman, 1974).

${ }^{3}$ Habit formation is another explanation for the coincidence of high income growth rates and high saving rates (e.g. Carroll and Weil, 1994). Yet, it cannot easily explain why consumption growth is on average negative in the second part of the life cycle.
} 
nomenon, since they potentially suffer from omitted variable biases (Gourinchas and Parker, 2002). Browning and Crossley (2001, p.14) conclude that "richer data is needed to resolve the source of the consumption tracking of income seen in the data."

This paper exploits the natural experiment of German reunification. Using this experiment allows me to distinguish more clearly than studies based on the comovement of consumption and income between different saving motives. For East Germans, German reunification signified a large shock to labor and retirement incomes, as well as to wealth levels. I investigate whether the saving behavior of East Germans after reunification is consistent with predictions from the life cycle consumption model. Moreover, I analyze the relative importance of precautionary saving, demographics, and retirement saving for the success of the model in replicating the empirical features. To this end, I study the saving behavior of the working population, ${ }^{4}$ and find three stylized empirical facts: (i) East Germans have higher saving rates than West Germans of any given age and cohort after reunification, (ii) this East-West saving rate difference is larger for older birth cohorts, and (iii) this East-West difference is decreasing over time for every cohort.

In the theoretical analysis, I build a comprehensive life cycle model, encompassing a retirement period, stochastic labor income, a liquidity constraint, age-dependent survival probabilities, as well as changing demographics over the life cycle. I calibrate and solve the model separately for East and West Germans, and separately for each East German birth cohort. The identification is driven by exogenous variations of the net present value of the economic shock of reunification for people at different stages of their life cycles. For example, reunification had different economic implications

\footnotetext{
${ }^{4}$ For an analysis of the saving behavior of Germans during the retirement period, see Börsch-Supan et al. (2001b). Further, Börsch-Supan et al. (2001a) give a description of saving behavior of West Germans before and shortly after reunification.
} 
for an East German who was born in 1970 and was at the beginning of her life cycle in 1990, than for an East German who was born in 1930 and was close to retirement age at the time of reunification. The most striking difference between East and West Germans lies in their initial wealth holdings at reunification. East German households had accumulated far less wealth than their West German counterparts of the same age, which was especially true for older households. These wealth differences can be taken as exogenous, since they arise due to the effects of living under a different economic regime for up to 45 years, rather than due to preference parameters. ${ }^{5}$

The calibrated model is able to replicate the three empirical saving rate features remarkably well. I conclude that the East German population acted in line with the life cycle hypothesis after the large economic shock of reunification. In a decomposition analysis, I find that the precautionary saving motive is essential in replicating the convergence between East and West German saving rates over the 1990s. Thus, the natural experiment of reunification provides strong evidence that precautionary saving is a necessary component if one wants to explain saving and consumption over the life cycle.

The next section summarizes the effects of the natural experiment, i.e. the influence of German reunification on East Germans, and gives a brief description of the data used in this study. Section 3 derives the three stylized saving facts in a graphical analysis, and confirms their significance in a regression analysis. Section 4 introduces the life cycle model, and presents the calibration. Section 5 discusses the performance of the model in replicating the East-West saving rate differences. Moreover, it analyzes the relative importance of different saving motives for the success of the

\footnotetext{
${ }^{5}$ Arguably, German reunification came as a surprise, and thus East German households did not plan ahead with German reunification in mind before 1989.
} 
model. It also investigates the effects of alternative expectations. The last section concludes.

\section{Institutional Features and Data}

\subsection{German Reunification}

After the fall of the Berlin Wall on November 9, 1989, the events towards a political and economic reunification of East and West Germany proceeded at a fast speed, culminating in reunification on October 3, 1990.

The East German currency was abolished on July 1, 1990. The exchange rate from Mark (East) into Deutsche Mark was 1:1 for small amounts of accumulated wealth, and 2:1 for amounts of wealth above a certain age-dependent threshold per person. ${ }^{6}$ Private debt was exchanged at the rate $2: 1$, while pension rights and wage contracts were transformed 1:1 (Sinn and Sinn, 1991). Section 4.2.1 provides detailed evidence on financial and real wealth holdings at reunification.

Nominal household incomes in the East, including transfers and social security payments, rose from around $35 \%$ of the West level in the spring of 1990 to about $80 \%$ in 1994 . From 1996 on, they have stagnated at around $85 \%$ of the West level (Sinn, 2002). The general perception seems to be that further convergence of nominal incomes will not occur in the near future. Retirement payments for East Germans are calculated using the West German formula, but taking East German labor incomes as a reference point (Sinn and Sinn, 1991). ${ }^{7}$ The replacement ratio in Germany is comparatively high, with retirement income equaling around $70 \%$ of the average labor income over

\footnotetext{
${ }^{6}$ East Germans less than 15 years old could exchange 2000 Mark (East) at the rate 1:1 into Deutsche Mark, while East Germans between 15 and 60 years could exchange 4000 Mark (East), and East Germans older than 60 years 6000 Mark (East) at this more favorable rate (Sinn and Sinn, 1991). 1000 Deutsche Mark corresponded to around $\$ 630$ in July 1990.

${ }^{7}$ As a result, on average the gap between East and West retirement payments corresponds to the gap between East and West labor incomes.
} 
the working life. The average nominal pension income per household in the East exceeds the average pension income per household in the West since 1995 (Sinn, 2002). This is mainly caused by the higher female labor market participation rate in the GDR than in the FRG. However, due to the lower age of exit from the labor force in East Germany after reunification (see e.g. Börsch-Supan and Schmidt, 2001), and due to the rapidly declining female employment rate (see e.g. Bonin and Euwals, 2002), the social security wealth of an average working East German household at reunification should not be larger than that of a West German household. Section 4.2.2 estimates the labor income processes of East and West Germans after reunification.

\subsection{Data}

The data used to analyze the saving behavior come from the German Socio-Economic Panel (GSOEP). ${ }^{8}$ This annual household panel survey was started in West Germany in 1984. From 1990 on, it covers also the territory of the former German Democratic Republic. I use the survey rounds from 1992 to 2000, since the question concerning financial saving was only introduced in 1992. GSOEP is the only German household survey that provides a panel. Moreover, the biggest advantage of GSOEP lies in the fact that it allows the researcher to identify where households lived before reunification, which determines the current and future economic conditions of the household. I use the original sample established in 1984, and the subsample covering the territory of the former GDR started in the summer of 1990. Households from the former sample are defined as West Germans, and households from the latter as East Germans. Thus, East and West always refer to the residence before reunification, independent of the residence in the observation year, unless

\footnotetext{
${ }^{8}$ Due to German data protection laws, researchers outside of Germany can only work with a $95 \%$ random sample of the full Socio-Economic Panel data set. A detailed description of the survey can be found in SOEP Group (2001).
} 
otherwise noted.

The saving data in the survey are recorded at the level of the household. I define the birth cohort of a household based on the birth year of the head of household. Because of the focus on labor force participants, I exclude households whose head is retired, but include households whose head is unemployed. I drop households whose head serves an apprenticeship. Further, I keep only households whose head is at least 20 years old at reunification, and not older than 65 in 2000 . The final sample size consists of 23,959 observations for the years 1992 to 2000, namely 14,874 observations in the West sample, and 9,085 observations in the East sample.

The total saving variable consists of positive financial saving and real saving, i.e. the amortization payments for owner-occupied housing and other dwellings. This variable is left-censored at real saving for those who report zero financial saving. The saving rate is defined as the ratio of total saving to net disposable household income, and is constructed for every household-year observation. Both financial saving and income are directly reported in the survey, ${ }^{9}$ while real saving is derived from information on home ownership and mortgage payments. The question regarding financial saving asks for saving in a "usual" month, thus averaging out seasonal fluctuations. ${ }^{10}$ Details of the construction of financial and real saving, as well as a discussion of the data and a comparison to data provided by the German Central Bank, are given in appendix A. All nominal variables are

\footnotetext{
${ }^{9}$ The question about financial saving reads: "Do you usually have an amount of money left over at the end of the month that you can save for larger purchases, emergency expenses or to acquire wealth? If yes, how much?". The question regarding household income reads: "If you take a look at the total income from all members of the household: how high is the monthly household income today? Please state the net monthly income, which means after deductions for taxes and social security. Please include regular income such as pensions, housing allowance, child allowance, grants for higher education, support payments etc. If you do not know the exact amount, please estimate the amount per month."

${ }^{10}$ The question concerning monthly income, on the other hand, asks for income "today". Note that more than $90 \%$ of the surveys are carried out between January and May, thus omitting December, in which households sometimes receive a 13 th monthly salary.
} 
in DM and are adjusted to represent purchasing power in 2000. In accordance with the residence in the observation year, inflation rates are taken from the CPI in Eastern or Western Germany until the year 1999, and from a common CPI from 2000 on.

In the calibration, I recur to two additional German data sets, namely the Income and Expenditure Survey (EVS), and the Microcensus. Both surveys are repeated cross-sections. The relevant samples for my purposes are the EVS from 1993, 1998, and 2003, and the Microcensus from 1991, 1993, and from 1995 on. ${ }^{11}$ Both surveys have the advantage that they exhibit larger sample sizes than GSOEP. Yet, both share the disadvantage that they do not allow one to identify where households lived before reunification. Thus, the distinction into East and West Germans has to be done based on the current residence of the household in both surveys.

\section{Empirical Results}

This section analyzes the saving behavior of East and West Germans after reunification, before the following two sections investigate whether a comprehensive life cycle model can explain this behavior.

\subsection{Three Stylized Facts}

In the GSOEP sample from 1992 to 2000, the average saving rate of West Germans is largely stable at around 12 percent (Figure 1). ${ }^{12}$ The average saving rate of East Germans is declining over time, from almost 15 percent in 1992 to around 11.5 percent in 2000. The figure includes 90 percent

\footnotetext{
${ }^{11}$ EVS is only carried out every five years. The scientific user files of the Microcensus are available annually since 1995, and bi-annually before that.

${ }^{12}$ The average saving rate is defined as the average of the household saving rates.
} 


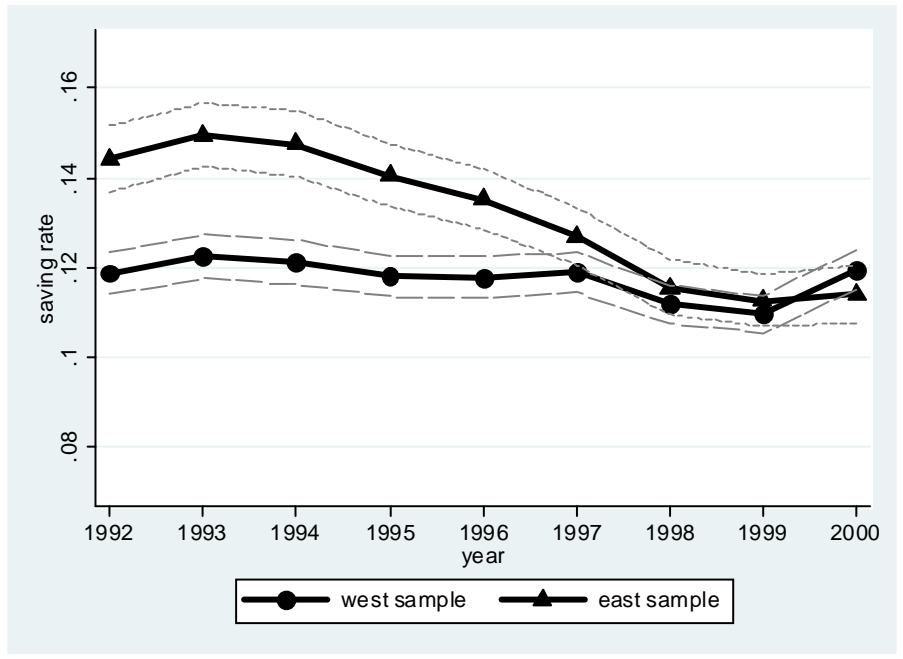

Figure 1: Average saving rate in West and East sample, 1992 to 2000. "East" and "West" refer to residence in GDR or FRG before reunification. 90 percent confidence bands from a bootstrap analysis are included.

confidence intervals from a non-parametric bootstrap with 5000 repetitions. ${ }^{13}$

Figure 2 shows how different cohorts' mean saving rates change over time in the East and West samples, grouping cohorts of five adjacent birth years together. ${ }^{14}$ The saving rates are generally higher for households from the former GDR (right panel) than for households who lived in the West before reunification (left panel). Moreover, they tend to be declining over time for every cohort in the East sample, while they are rather flat over time in the West sample.

Figure 3 is a central figure for this paper. It depicts the East-West differences of the cohortage profiles of the saving rate, ${ }^{15}$ as well as 90 percent confidence intervals from a non-parametric

\footnotetext{
${ }^{13}$ I follow the procedure suggested in Levinsohn and Petrin (2003), treating each set of household-level observations together as an independent, identical draw, and sampling with replacement and equal probabilities from the sets of household-level observations in the original data. A bootstrap analysis of the East-West saving rate difference shows that it is significantly positive in 1992 and in the following years up to 1996, and significantly smaller at the end of the sample period than at the beginning, both even at the 5 percent significance level. Results are available from the author upon request.

${ }^{14}$ Since the cell sizes are very small for the oldest and youngest cohorts if the East data is broken up into cohorts, the figure only shows cohorts born between 1943 and 1967. The regression in section 3.2 however includes all observations.

${ }^{15}$ To enhance readability, each cohort group is represented in a different subfigure.
} 
bootstrap, and exhibits three features:

1. The differences in the saving rates between East and West Germans of any given birth cohort are positive in 1992, and mostly remain positive over the following eight years.

2. The initial East-West saving rate difference is larger for older birth cohorts.

3. The difference is decreasing over time for every cohort.

The East-West saving rate difference at the beginning of the sample period amounts to 1.7 percentage points for the cohorts less than 30 years old in 1992, around 2.5 percentage points for the cohorts between 30 and 40 years old in 1992, and around 4.5 percentage points for the cohorts older than 40 in $1992 .{ }^{16}$ This difference is significantly positive for each but the youngest cohort group. ${ }^{17}$ Yet, the bootstrapped confidence intervals cannot establish that the initial East-West saving rate difference is significantly larger for the older cohort groups.

The average annual decline in the East-West saving rate difference over the following years lies between 0.42 and 0.75 percentage points for the five cohort groups, and averages 0.57 percentage points. For all but the second youngest cohort group, the saving rate difference at the end of the sample period (in either 1999 or 2000) is significantly smaller than the saving rate difference at the beginning of the sample period (in either 1992 or 1993). ${ }^{18}$

\footnotetext{
${ }^{16}$ For the oldest two cohort groups, this maximum saving rate difference occurs in 1993.

${ }^{17}$ This is true even based on 95 percent confidence intervals.

${ }^{18}$ For the second oldest cohort group, the minimum saving rate difference occurs in 1999. For the second youngest cohort group, the saving rate difference at the end of the sample period is significantly smaller than the one at the beginning of the sample period only at the 15 percent significance level.
} 

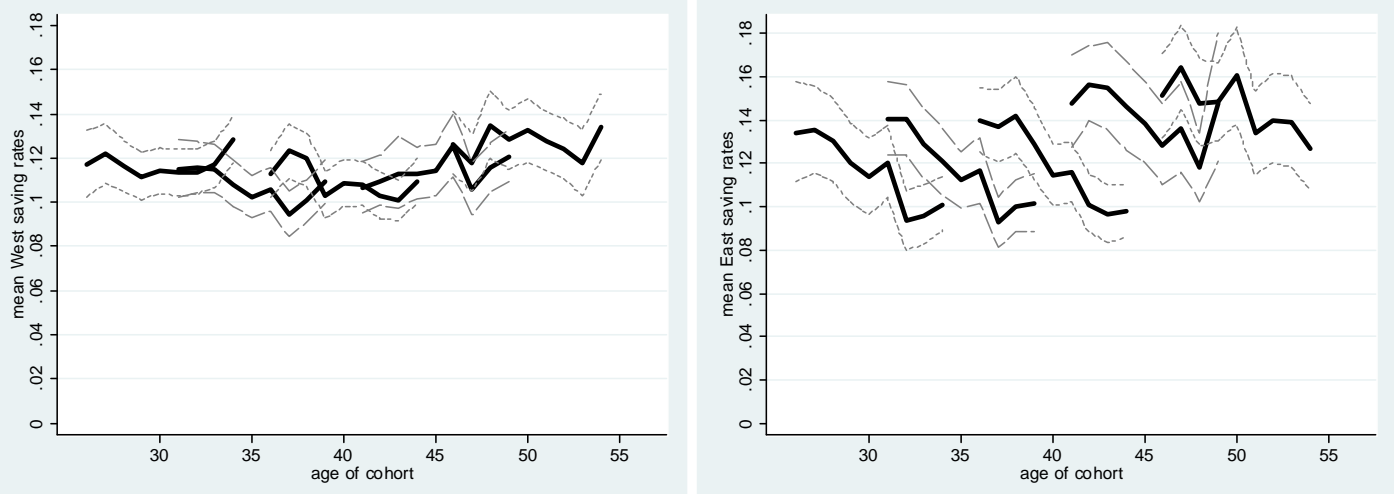

Figure 2: Cohort-age profiles of saving rate in West sample (left panel) and East sample (right panel). "East" and "West" refer to residence in GDR or FRG before reunification. Each solid line represents five adjacent birth cohorts. 90 percent confidence bands from a bootstrap analysis are included.
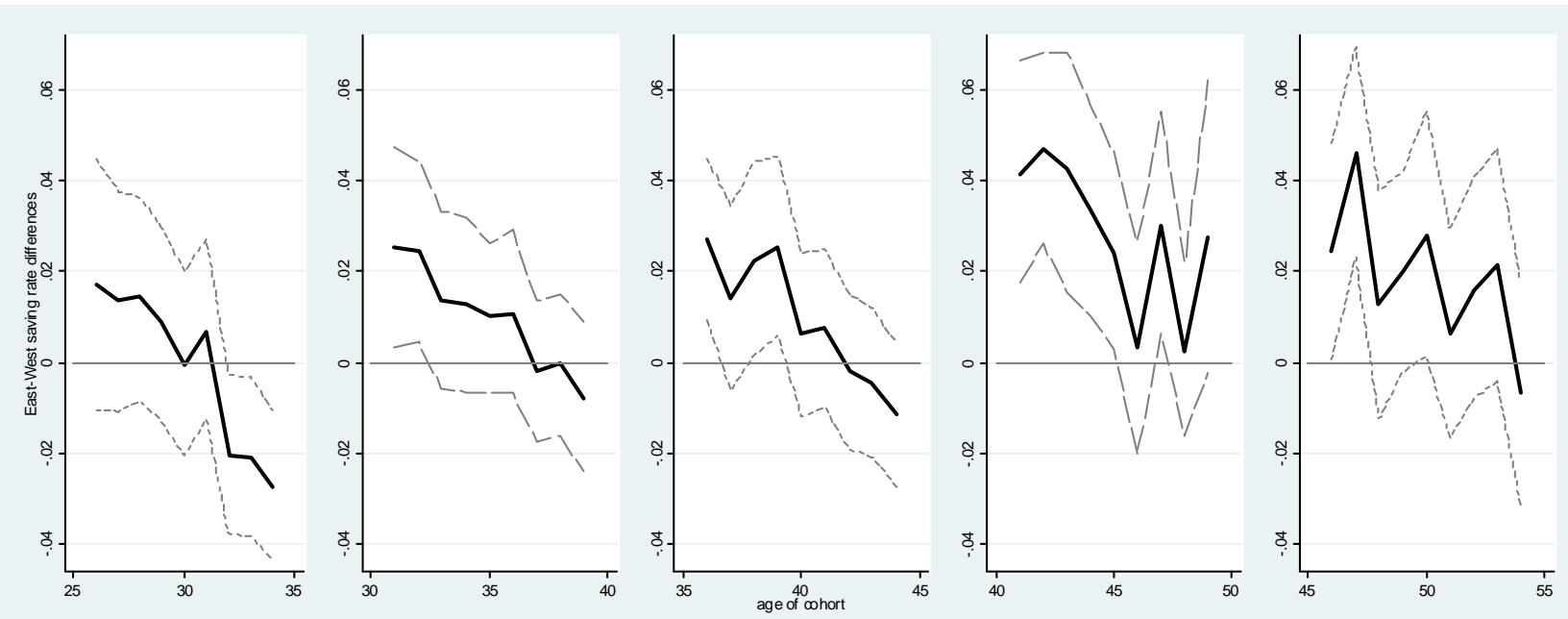

Figure 3: Cohort-age profiles of East-West difference of saving rate. "East" and "West" refer to residence in GDR or FRG before reunification. Each solid line represents five adjacent birth cohorts. 90 percent confidence bands from a bootstrap analysis are included.

\subsection{Regression Analysis}

The theoretical part of this paper analyzes whether the life cycle consumption model is able to replicate these three features. Before doing that, this section analyzes the statistical significance 
of the three saving rate features in a regression analysis, which allows me to explicitly take care of the censoring of one component of the saving variable, namely financial saving. Moreover, the regression imposes some minimal parametric structure, namely that the convergence of the EastWest saving rate difference over time is the same for all cohorts. The imposition of this parametric structure increases the statistical significance of the three features.

Since saving is left-censored at real saving if reported financial saving is zero, random-effects tobit models are estimated on the following equation

$$
\left(\frac{S}{Y}\right)_{i, t}=b_{i}^{\prime} \alpha_{0}+\left(b_{i} * \text { east }_{i}\right)^{\prime} \alpha_{1}+\text { year }_{t}^{\prime} \alpha_{2}+\left(\text { year }_{t} * \text { east }_{i}\right)^{\prime} \alpha_{3}+\varepsilon_{i, t}
$$

where $S$ is saving and $Y$ is disposable income. The dummy east takes on the value 1 if the household lived in East Germany before reunification. $b$ is a vector of cohort group dummies, and year is a vector of year dummies. I group households into four cohort groups according to their birth cohort: those born between 1935 and 1942, between 1943 and 1951, between 1952 and 1960, and between 1961 and 1969. In the regression, the complete set of cohort dummies is included, but the dummy for the year 1992 is omitted. ${ }^{19}$

The estimation results in Table 1 confirm the three stylized facts from the graphical analysis. First, all four coefficients on the interaction terms of the cohort group dummies with the East dummy are positive, indicating that East Germans exhibit higher saving rates than West Germans of the same age in 1992. These East-West differences are statistically significant except for the youngest cohort group. Second, the coefficients on the interaction terms between the East dummy

\footnotetext{
${ }^{19}$ Alternatively, I can impose additional parametric structure and regress the saving rate linearly on the birth year and on a linear time trend, also including interactions of both variables with the East dummy. The interaction terms of this regression have the expected signs and are significant at the one percent significance level.
} 


\begin{tabular}{|l|cc|}
\hline Dependent variable: saving rate & coeff. $\left({ }^{*} 100\right)$ & std. err. $\left({ }^{*} 100\right)$ \\
\hline \hline born 1961-1969 & $8.251^{* * *}$ & 0.627 \\
born 1952-1960 & $7.057^{* * *}$ & 0.608 \\
born 1943-1951 & $8.168^{* * *}$ & 0.640 \\
born 1935-1942 & $10.776^{* * *}$ & 0.649 \\
born 1961-1969*east & 1.119 & \\
born 1952-1960*east & $1.977^{* *}$ & 0.988 \\
born 1943-1951*east & $4.222^{* * *}$ & 0.914 \\
born 1935-1942*east & $4.549^{* * *}$ & 0.972 \\
& & 1.102 \\
year 1993 & 0.097 & 0.407 \\
year 1994 & 0.311 & 0.405 \\
year 1995 & -0.343 & 0.408 \\
year 1996 & -0.190 & 0.409 \\
year 1997 & -0.047 & 0.408 \\
year 1998 & $-0.821^{* *}$ & 0.410 \\
year 1999 & -0.619 & 0.411 \\
year 2000 & $0.763^{*}$ & 0.416 \\
year 1993*east & & \\
year 1994*east & 0.691 & 0.649 \\
year 1995*east & -0.177 & 0.647 \\
year 1996*east & -0.524 & 0.650 \\
year 1997*east & $-1.162^{*}$ & 0.652 \\
year 1998*east & $-1.761^{* * *}$ & 0.652 \\
year 1999*east & $-2.331^{* * *}$ & 0.660 \\
year 2000*east & $-3.104^{* * *}$ & 0.662 \\
\hline obs & $-3.540^{* * *}$ & 0.669 \\
log likelihood & 23,959 & \\
\hline Notes Rang & 6,089 & \\
\hline
\end{tabular}

Notes: Random effects tobit regression. All coefficients and standard errors are multiplied by 100 . The omitted year dummy is 1992. Standard errors with an $*$ indicate that the estimate is significant at $10 \%$ level, $* *$ at $5 \%$ level, $* * *$ at $1 \%$ level.

Table 1: Estimation results

and the cohort dummies are increasing in the age of the cohort. Wald tests confirm that the EastWest saving rate differences in 1992 are significantly larger for the two oldest cohort groups than for both the cohort group born 1961 to 1969 and the cohort group born 1952 to 1960 at the 5 percent 
significance level. However, the East-West differences between the two youngest cohort groups are not significantly different, nor are they significantly different between the two oldest cohort groups. Hence, the estimates indicate that the saving rate differences between East and West in 1992 are significantly larger for older cohorts than for younger ones, but only based on a comparison of the older half of the sample cohorts to the younger one. The point estimates confirm the magnitudes of the saving rate differences in 1992 shown in Figure $3 .^{20}$ Third, the interaction terms between the year dummies and the East dummy indicate that the East-West saving rate difference is almost linearly decreasing over time. The only exception to this is the period between 1992 and 1993, when the difference is actually slightly increasing. The East-West saving rate differences of the years 1996 and later are significantly smaller than the difference in $1992 .{ }^{21}$ On average, the East-West saving rate declines by 0.6 percentage points per year from 1993 on. Summarizing, the regression results yield similar magnitudes for the East-West saving rate differences as those shown in Figure 3, and confirm the statistical significance of the three stylized facts.

\section{The Life Cycle Consumption Model}

The theoretical part of this paper investigates whether the observed saving behavior after reunification is consistent with predictions of a comprehensive life cycle consumption model. The model encompasses a retirement period, stochastic labor income, a liquidity constraint, deterministic agedependent household sizes, and age-dependent survival probabilities, and thus largely follows the

\footnotetext{
${ }^{20}$ The truncation of financial saving leads to lower predicted saving rates in both East and West than those shown in Figure 2. However, the East-West difference is essentially unaffected by the truncation, which concerns the East and West samples to a similar degree.

${ }^{21}$ Moreover, Wald tests show that the East-West saving rate differences in 1996, 1997, 1998, 1999, and 2000 are significantly smaller than the respective differences three years earlier (i.e. in 1993, 1994, 1995, 1996, and 1997) at the one percent significance level.
} 
model presented in Gourinchas and Parker (2002).

\subsection{The Model}

Let the last period of the working life be denoted by $R$, and the last period of the maximization problem, after which death occurs with probability one, by $T$. The household solves the following utility maximization problem:

$$
\max _{\left\{C_{t}\right\}_{t=0}^{T}} \sum_{t=0}^{T} \beta^{t}\left(\prod_{j=0}^{t} s_{j}\right) E_{0}\left\{u_{t}\left(C_{t}\right)\right\}
$$

with

$$
u_{t}\left(C_{t}\right)=n_{t} \frac{\left(\frac{C_{t}}{n_{t}}\right)^{1-\gamma}}{1-\gamma}
$$

where $u_{t}\left(C_{t}\right)$ is the utility function in period $t,{ }^{22} n_{t}$ equals effective household size in period $t, C_{t}$ is household consumption in period $t$, and $s_{j}$ are age-dependent survival probabilities. ${ }^{23} \beta$ is the discount factor, and $\gamma$ the coefficient of relative risk aversion. Moreover, let $Y_{t}$ be income, $A_{t}$ wealth at the beginning of the period, and $r$ the risk-free interest rate. The utility maximization is subject to a budget constraint

$$
A_{t+1}=(1+r)\left(A_{t}+Y_{t}-C_{t}\right)
$$

and subject to a liquidity constraint

$$
A_{t+1} \geq 0 \quad \forall t
$$

Labor income grows with an age-specific rate, and is subject to a temporary and a permanent shock. Both shocks are log-normally distributed. Retirement income is deterministic and equals a

\footnotetext{
${ }^{22}$ The subscript indicates that utility in period $t$ depends on the deterministic effective household size at time $t$.

${ }^{23} s_{j}$ is defined as the survival probability between $j-1$ and $j$, with $s_{0}=1$.
} 
fraction $\eta$ of the permanent income in the last period of the working life. Thus,

$$
Y_{t}= \begin{cases}P_{t} \epsilon_{t} & \text { for } t \leq R \\ \eta P_{t} & \text { for } t>R\end{cases}
$$

with

$$
P_{t+1}=\left\{\begin{array}{cc}
G_{t+1} P_{t} \mu_{t+1} & \text { for } t \leq R \\
P_{t} & \text { for } t>R
\end{array}\right.
$$

and

$$
\log \epsilon_{t} \sim N\left(-\frac{\sigma_{\epsilon}^{2}}{2}, \sigma_{\epsilon}^{2}\right), \quad \log \mu_{t} \sim N\left(-\frac{\sigma_{\mu}^{2}}{2}, \sigma_{\mu}^{2}\right)
$$

where $P_{t}$ is the permanent component of income, $G_{t}$ is the deterministic age-dependent gross growth rate of the permanent component of income, $\epsilon_{t}$ is a transitory income shock, and $\mu_{t}$ is a permanent income shock.

Denote as $X_{t}$ cash at hand at the beginning of the period (i.e. $X_{t} \equiv A_{t}+Y_{t}$ ). The Bellman equation of the problem is then

$$
\mathcal{V}_{t}\left(X_{t}, P_{t}\right)=\max _{\left\{C_{t}\right\}}\left\{u_{t}\left(C_{t}\right)+\beta s_{t+1} E_{t}\left[\mathcal{V}_{t+1}\left(X_{t+1}, P_{t+1}\right)\right]\right\}
$$

Following Carroll (1992), I solve the problem numerically by backward induction on the transformed value function $V_{t}\left(x_{t}\right)$. Denote variables divided by permanent income by small letters (i.e. $\left.x_{t} \equiv \frac{X_{t}}{P_{t}}\right)$, and define $V_{t}\left(x_{t}\right) \equiv P_{t}^{1-\gamma} \mathcal{V}_{t}\left(x_{t}\right)$. The Bellman equation then simplifies to

$$
V_{t}\left(x_{t}\right)=\max _{\left\{c_{t}\right\}}\left\{u_{t}\left(c_{t}\right)+\beta s_{t+1} G_{t+1}^{1-\gamma} E_{t}\left[\mu_{t+1}^{1-\gamma} V_{t+1}\left(x_{t+1}\right)\right]\right\}
$$

subject to the budget constraint

$$
x_{t+1}=\frac{1+r}{\mu_{t+1} G_{t+1}}\left(x_{t}-c_{t}\right)+\epsilon_{t+1}
$$

and the liquidity constraint

$$
x_{t} \geq c_{t} .
$$




\subsection{Parametrization and Calibration}

The model has to be calibrated separately for East and West Germans. Moreover, since for East Germans the 1990s were a clear period of transition, and the age at reunification had not only an influence on the relative initial wealth holdings, but also on the income prospects and demographic development, I calibrate the model separately for every East German birth cohort. In the data, I control for any cohort effects of West Germans, which are comparatively small, and consequently abstract from cohort effects for West Germans in the model. Since cell sizes become small if the East German sample is divided into year-cohort cells, I often impose additional assumptions to smooth the data and minimize the effect of measurement error. All of these assumptions are discussed explicitly in the respective subsections. Since I can observe the empirical saving rate only from 1992 on, I calibrate and simulate the model from that year on.

Preference parameters are assumed to be equal between East and West Germans. The interest rate is set to $r=0.0184$, the average real interest rate on saving accounts in Germany over the period 1992 to 2000. Working life consists of 45 periods $(R=45)$, reflecting ages 20 to 64 . Consequently, for the East I model the cohorts between 20 and 64 years old in 1992, i.e. born between 1928 and 1972. Each household is assumed to live a maximum of 81 periods $(T=81)$, i.e. death occurs with probability one after age $100 .{ }^{24}$ I use average age-dependent survival probabilities of males and females, which are provided separately for East and West Germans by the German Statistical Office for the years 2002-2004. The East-West differences in survival probabilities are small. ${ }^{25}$

\footnotetext{
${ }^{24}$ Survival probabilities are not available for Germany beyond the age of 100 .

${ }^{25}$ The average life expectancy of a West German male aged 20 is 1.46 years longer than that of an East German male of the same age, while the difference for females of the same age amounts to only 0.39 years. For individuals of age 50, the corresponding differences in life expectancy are 0.96 years for males, and 0.36 years for females. For the survival probabilites, I abstract from cohort effects in both East and West.
} 


\subsubsection{East German Wealth Holdings at Reunification}

The most important difference between East and West Germans arises through their wealth levels at reunification. West Germans are assumed to start life with zero wealth, i.e. $A_{0}=0$, and then accumulate wealth over the life cycle according to the optimal policy function. I model the impact of reunification as causing an exogenous variation in wealth levels at reunification, endowing East Germans with lower than the optimal wealth levels they would have acquired would they have lived in West Germany from birth on.

I use data on financial income as well as information on home and car ownership from the German Socio-Economic Panel survey round of 1992 in order to build a comprehensive measure of household wealth. Financial wealth is constructed based on information on interest and dividend income, and housing wealth is constructed from information on home ownership and mortgage payments. Both procedures are detailed in Fuchs-Schündeln and Schündeln (2005). Fuchs-Schündeln and Schündeln (2005) also compare the financial and housing wealth measures to data from the Income and Expenditure Survey (EVS), and provide evidence that the measures match financial wealth and housing wealth for East and West Germans from the EVS reasonably well. Last, GSOEP provides information whether the household owns at least one car. I construct the average value of cars per car-owning household in 1993 based on data from the EVS separately for East and West Germans (see appendix B.1 for a detailed description). The respective amounts are added to the wealth of East and West German households in GSOEP who indicate car ownership.

Figure 4 shows the average wealth holdings of East and West Germans by birth cohort in 


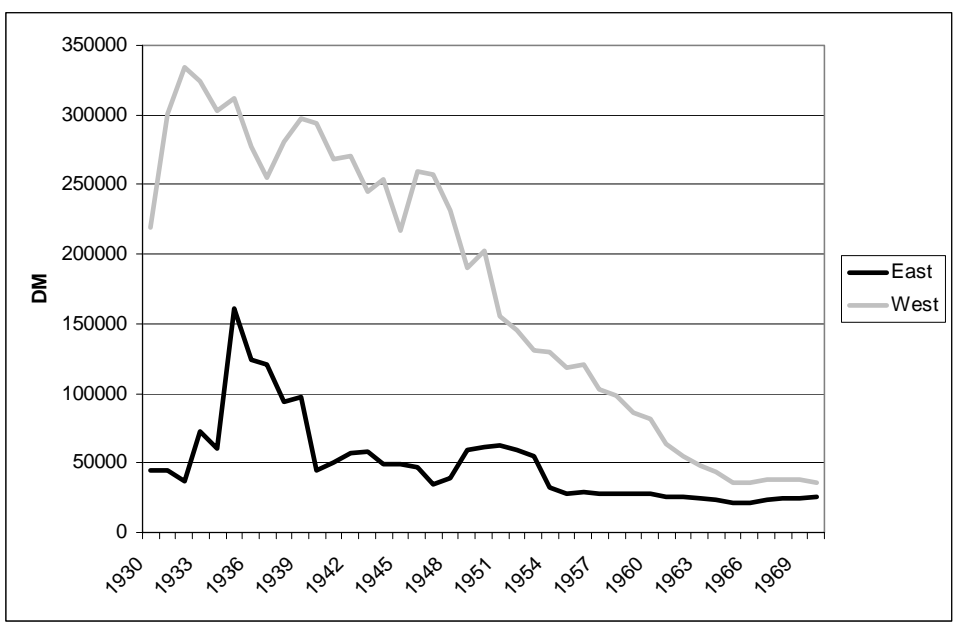

Figure 4: Average household wealth in East and West in 1992 by birth cohort.

1992. ${ }^{26}$ While in both parts of Germany wealth holdings are increasing in the age of the birth cohort, the East-West difference is clearly increasing in the age of the cohort. One would expect the wealth difference to be larger for older cohorts, since they lived under separate regimes for a longer time. I construct the East-West ratio of average household wealth for each cohort, and regress the resulting ratios on a linear trend (see Table 2). The estimation results imply that in 1992 the average wealth of East households born in 1928 amounted to only 13 percent of the average wealth of West households of the same age, while the average wealth of East households born in 1972 was 56 percent of the wealth of their West German counterparts. The estimated East-West wealth ratios are used to calibrate the wealth holdings of East Germans in 1992 in the simulations of the consumption model.

\footnotetext{
${ }^{26}$ Due to small cell sizes, the graph shows moving averages of five adjacent birth cohorts.
} 


\begin{tabular}{|c|cc|}
\hline $\begin{array}{c}\text { dependent variable: } \\
\text { wealth ratio }\end{array}$ & Coeff. & Std. Err. \\
\hline \hline trend & 0.009 & 0.002 \\
constant & 0.148 & 0.039 \\
\hline$R^{2}$ & 0.46 & \\
\hline
\end{tabular}

Table 2: Regression of East-West ratios of average cohort wealth holdings in 1992 on a constant and a cohort trend.

\subsubsection{Income}

Levels and Growth Rates West Germans are assumed to start life with permanent income normalized to $P_{0}=1$. To calculate the deterministic life-cycle growth rate of income over the working life, $G_{t}$, I use data from the original West German GSOEP sample from 1984 to 2002. The logarithm of deflated disposable household income is regressed on a complete set of cohort dummies, a fourth order polynomial in age, and the state-level unemployment rate of the respective year. ${ }^{27}$ I derive age-dependent income growth rates based on the predicted incomes for ages 20 to 64 from this regression, holding the cohort and the unemployment rate constant. ${ }^{28}$ The predicted annual income growth rate is slightly higher than five percent for the youngest households, and becomes negative at age 56. Thus, the income profile over the working life exhibits a hump.

The underlying life cycle income growth path for East Germans is assumed to be the same as for West Germans. ${ }^{29}$ However, income convergence after reunification led to additional income growth for East Germans in the early 1990s. In the second half of the 1990s, this convergence came to a

\footnotetext{
${ }^{27}$ The sample includes households whose heads are in the labor force and between 22 and 63 years old. Households with younger and older heads are excluded, since the number of observations in these age groups is very small, and self-selection plays an important role. Including households aged 64 would result in only small changes. However, including the youngest households would lead to very large predicted growth rates between ages 20 and 23 , due to the fact that higher educated people enter the sample at a later age.

${ }^{28}$ Predicted income is derived for the youngest cohort, assuming that the unemployment rate always equals the mean sample unemployment rate. Note that the choice of the cohort or the unemployment rate does not affect the predicted growth rates.

${ }^{29}$ Some suggestive evidence for this assumption is presented in Appendix B.2.
} 
halt, and incomes are on average still lower in the East than in the West.

As input into the model, I need to calibrate the East-West ratios of incomes by cohort in 1992, as well as the additional income growth rate of East Germans in the early 1990s. I impose the following two assumptions: ${ }^{30}$ first, the East-West ratio of incomes is linearly increasing in the birth year, and second, the growth rate of the cohort-specific East-West ratio of incomes over time is constant across cohorts for any given year. Based on these assumptions, I estimate cohort- and year-specific predicted East-West income ratios. Figure 5 shows the magnitudes of these predicted East-West income ratios for some sample cohorts, as well as the speed of the convergence. The details of the estimation are described in Appendix B.2. The estimated convergence of incomes stops in 1997. Cohort-specific East incomes by year are constructed by applying these ratios to the estimated West income. This procedure then leads to cohort-specific start levels of East incomes in 1992, as well as cohort-specific income growth rates. ${ }^{31}$

Income Risk The variances of the permanent and temporary income shocks are estimated as suggested by Carroll and Samwick (1997), separately for the East and West samples, using data from 1992 on. The procedure is explained in appendix B.3. The estimated variance of the temporary income shock is slightly larger in the East sample than in the West, while the estimated variance of the permanent income shock is slightly smaller, but the differences are never significant (see Table 3). The variance of the permanent income shock is estimated as $\sigma_{\mu}^{2}=0.012$, and the variance of the temporary income shock as $\sigma_{\epsilon}^{2}=0.038$.

\footnotetext{
${ }^{30}$ Both assumptions only serve to smooth measurement error due to small cell sizes. Appendix B.2 presents some evidence that these assumptions are reasonable.

${ }^{31}$ Thus, the cohort-specific East income growth rates are a function of the convergence process and the age-specific life-cycle growth rates.
} 


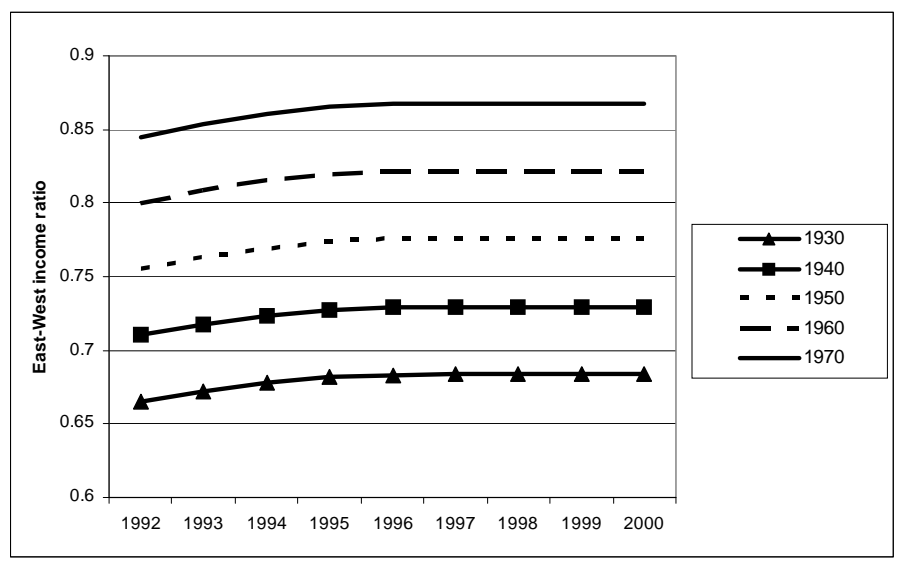

Figure 5: Estimated East-West income ratios 1992 to 2000 for selected birth cohorts.

\begin{tabular}{|c|cc|}
\hline & West sample & East sample \\
\hline \hline$\sigma_{\epsilon}^{2}$ & 0.03766 & 0.03777 \\
& $(0.00299)$ & $(0.00259)$ \\
$\sigma_{\mu}^{2}$ & 0.01194 & 0.01175 \\
& $(0.00112)$ & $(0.00097)$ \\
\hline
\end{tabular}

Note: Standard errors are in parentheses

Table 3: Estimated variances of the temporary and permanent income shocks.

The high unemployment rates in the East after reunification might cause the perception that East Germans faced higher income risk than West Germans (see also section 5.3.1). On the other hand, the wage distribution in the GDR was more compressed than in West Germany before reunification, and while wage dispersion in the East has been rising after reunification, it has not reached the West German level by the end of the sample period (see Biewen, 2000; OECD, 2001).

Retirement Income I set $\eta=0.57$, i.e. the retirement income is equal to 57 percent of the last permanent income during the working life. This leads on average to a replacement ratio of 70 percent with respect to the average income over the working life, a number which captures the 
replacement rate of the German Social Security System.

\subsubsection{Demographics}

The effective household size $n_{t}$ depends on the average household composition by age, as well as an appropriate adult equivalence scale. To calibrate the household composition, I recur to the Microcensus. ${ }^{32}$ For every household in the sample, I observe the number of adults and children. To translate family composition into adult equivalences, I use estimates of adult equivalence scales for West Germany by Faik and Merz (1995) based on the EVS. ${ }^{33}$ I then calculate the average adult equivalences by year and cohort separately for East and West. ${ }^{34}$ For households whose head is older than 75 , I assume that the adult equivalences are linearly declining.

For the West, I use as an input into the model the adult equivalences across ages in the year 2000. However, there exist cohort effects in the life-cycle shape of household composition in the West over the 1990s. These effects go beyond a simple level effect: not only is the household size on average larger for older cohorts, controlling for age, but the shape of the household composition over the life cycle also differs across cohorts. As an example, older cohorts tended to have children earlier in life. The adult equivalences are the only input variable for the West for which controlling for level cohort effects alone is not sufficient. Since the model set-up does not allow for cohort effects for West Germans, I instead choose to apply a transformation to the East data, such that the East-West difference in adult equivalences in fact takes the West cohort effects into account.

\footnotetext{
${ }^{32}$ Since it is hard to make reasonable assumptions to smooth measurement error when it comes to household composition, a large sample size is crucial. The Microcensus round of 2000, for example, contains observations on around 3,100 households per cohort in the West, and 675 per cohort in the East, an order of magnitude more than in GSOEP.

${ }^{33}$ For further information, see appendix B.4.

${ }^{34}$ To obtain values for 1992 and 1994, I average the cohort values for 1991 and 1993, and 1993 and 1995, respectively, separately for East and West.
} 


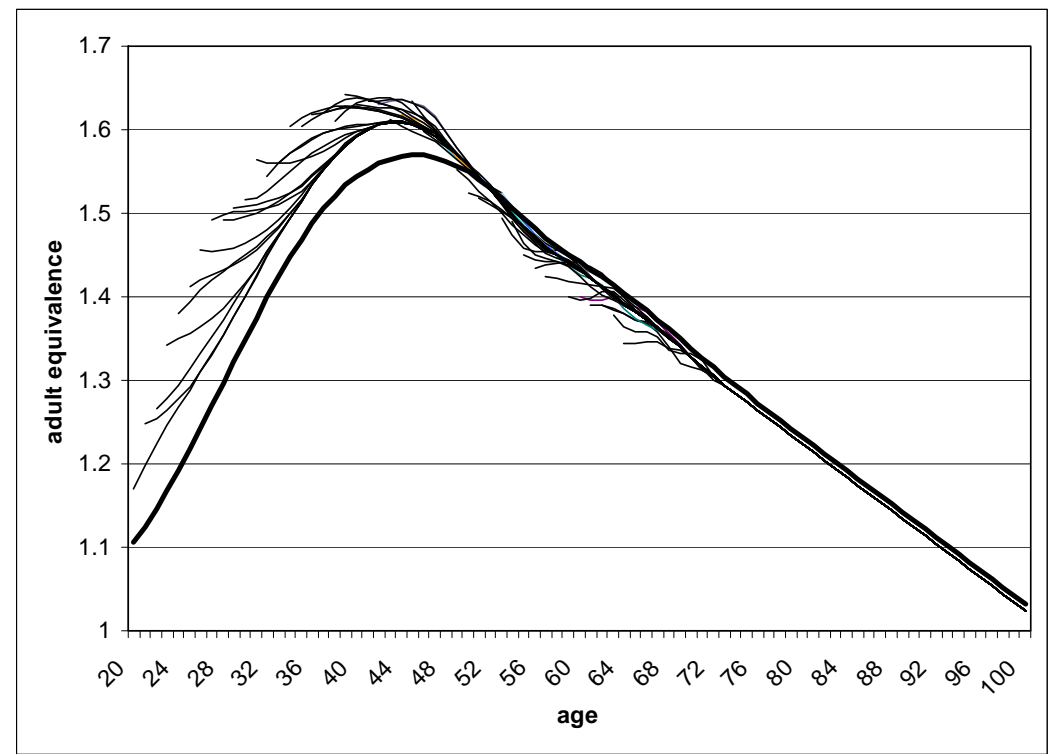

Figure 6: Estimated adult equivalences over the life cycle for West German households and different East German cohorts, born 1928 to 1972 (see text).

The exact procedure is described in appendix B.4.

Figure 6 shows the resulting input into the model. The thick line shows the adult equivalences of West German households by age, while the other lines show the adult equivalences for different East German cohorts, starting at left with the cohort born in 1972. Clearly, young East German cohorts have larger household sizes than the respective West German cohorts in 1992, since East Germans tended to have children earlier in life than West Germans. As a consequence of this, as well as the drastic decline in birth rates in the East after 1990, the increase in the household size is larger for young West Germans than for the respective East German cohorts over the 1990s. From age 50 on, the differences between East and West Germans become relatively minor. 


\subsubsection{Preference Parameters}

There are two preference parameters to be calibrated, namely the risk aversion parameter $\gamma$, and the discount factor $\beta$. I choose these parameters to match certain moments from the life cycle consumption profile of West Germans, namely the age at which consumption peaks, as well as the peak/start ratio of consumption, and the peak/retirement ratio. I estimate the life cycle profile of consumption over the working life based on the 1993, 1998, and 2003 rounds of the Income and Expenditure Survey (EVS). Consumption is measured as total expenditure, including durables expenditure, and the sample consists of all West German households whose head is younger than 65 years and not retired. ${ }^{35}$ The logarithm of consumption is regressed on a complete set of age dummies, a complete set of cohort group dummies, ${ }^{36}$ and the annual unemployment rates in the state of residence (see e.g. Gourinchas and Parker, 2002, for a similar specification). From this estimation I construct the predicted consumption path for a household of the middle cohort, keeping the unemployment rate fixed. ${ }^{37}$

Consumption peaks at age 50 . The peak-start ratio amounts to $2.48,{ }^{38}$ and the peak-retirement ratio to 1.11. Based on these moments, the discount factor is set to $\beta=0.96$, and the risk aversion parameter to $\gamma=2 .{ }^{39}$ The resulting simulated consumption profile peaks at age 50 , the peak-start

\footnotetext{
${ }^{35}$ Given the self-selection into early retirement, as well as likely non-separabilities between consumption and leisure, it is most appropriate to match this consumption profile.

${ }^{36}$ Since I only observe consumption every five years, I have to group five adjacent birth cohorts together.

${ }^{37}$ Note that the choice of the cohort and unemployment rate only influences the level of consumption, but none of the three moments of interest.

${ }^{38}$ Start consumption is defined as the average consumption between ages 20 and 21 . Consumption is declining in the data between ages 20 and 21, but continuously increasing from age 21 . If I define start as age 20, the peak-start ratio is 2.28 , while it is 2.73 if start is defined as age 21 .

${ }^{39}$ Gourinchas and Parker (2002) estimate a discount factor of 0.96 and a risk aversion parameter of between 0.5 and 1.4. The life-cycle consumption profile in the US differs however somewhat from the one in Germany (see e.g. Fernández-Villaverde and Krueger, 2005, who document the consumption profile in the US in a comparable way to the profile presented here, i.e. without controlling for family composition). This is consistent with different preference parameters in the US and Germany.
} 


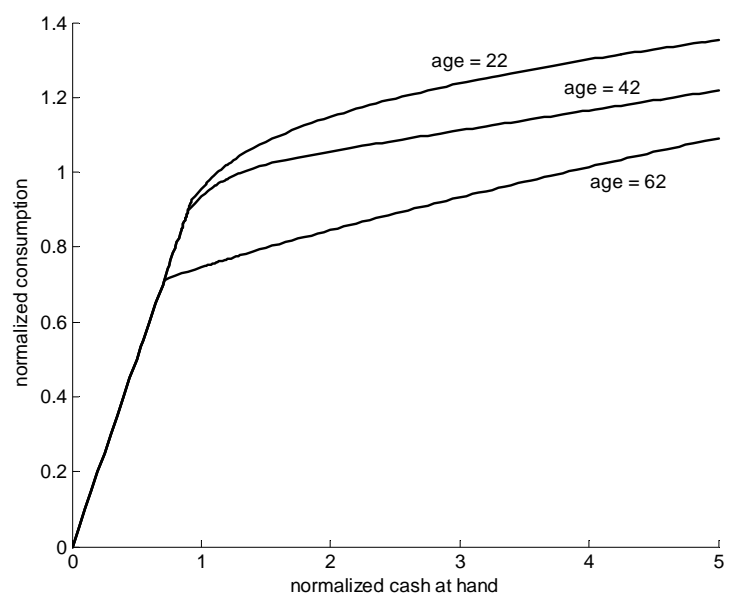

Figure 7: Consumption function of West German households aged 22, 42, or 62.

ratio amounts to 2.44 , and the peak-retirement ratio to 1.11 .

\section{Predictions of the Life Cycle Model}

After solving the model separately for West Germans and each East German cohort, I simulate 1 million life cycle paths of West Germans. Next, 1 million life cycle paths per East German birth cohort are simulated from 1992 on. As East Germans enter the economy in 1992, they are endowed with the calibrated shares of wealth holdings and incomes of West Germans of the corresponding age. By doing this, I assume that the variance of the wealth distribution of different cohorts is identical in 1992 in East and West. ${ }^{40}$ Note that assumptions about the initial income distribution in the East do not matter if one only analyzes the first moments of the distribution.

Figure 7 shows the optimal consumption function of West German households whose heads are 22, 42, or 62 years old, respectively. Consumption is increasing and concave in cash at hand.

\footnotetext{
${ }^{40}$ As I discuss in section 5.1, the results change only very slightly if one assumes the opposite extreme, namely that East Germans of a given birth cohort all have the same wealth level in 1992.
} 


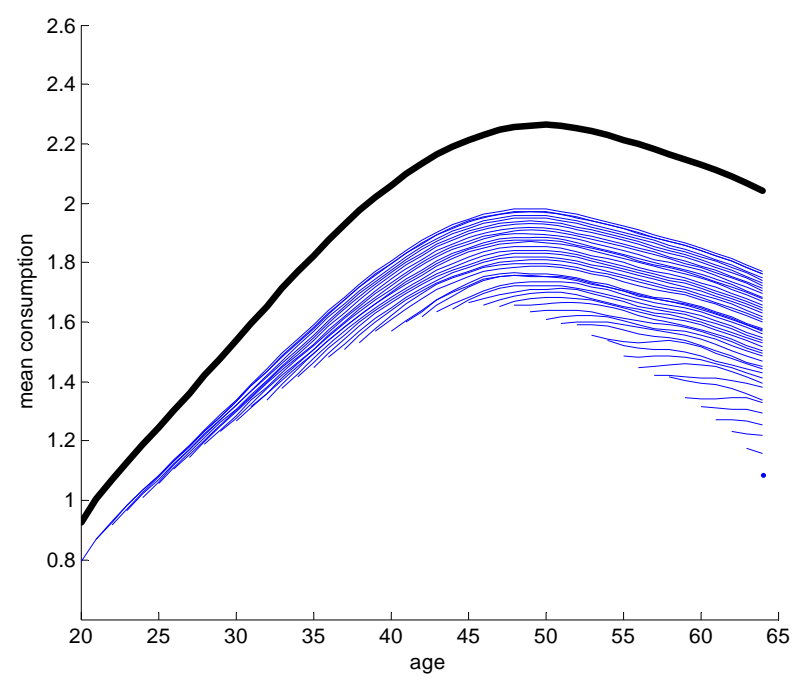

Figure 8: Mean consumption of West Germans and different East German cohorts in baseline calibration.

Moreover, for any given level of cash at hand, consumption declines as households approach retirement. $^{41}$

\subsection{Baseline Results}

Figure 8 shows the resulting consumption paths of West Germans and East German cohorts, constructed as means from 1 million simulations per cohort. The thick line corresponds to West Germans, while the thin lines represent East German cohorts, starting from left with the cohort born in 1972, thus being 20 years old in 1992, up to the cohort born in 1928, being 64 years old in 1992. The lower income levels and lower starting wealth of East German households are reflected in the gap between the consumption levels of the West and East German households, and in the fact that this gap is larger for older households. Except for some of the younger cohorts, the East-

\footnotetext{
${ }^{41}$ See Gourinchas and Parker (2002) for a more detailed discussion of the consumption function of a similar life cycle problem, and Carroll (1992) for a discussion of the consumption function in a model without a retirement period.
} 
West ratio of consumption is increasing over time. The differences in the consumption behavior between East and West Germans are more dramatic for older cohorts. While West Germans have a decreasing consumption path from age 50 on, the cohorts of East Germans who are 50 or older in 1992 still experience positive consumption growth, or at least a smaller decline, in the first years after reunification.

Figure 9 depicts the cohort-age profiles of the average East-West saving rate differences over the time period 1992 to $2000{ }^{42}$ This figure is analogous to Figure 3, and exhibits the same three stylized facts. First, for every cohort, East German saving rates are on average higher than West German saving rates. Second, the differences between East and West German saving rates are larger for older cohorts than for younger cohorts. Last, for the majority of cohorts the difference between East and West Germans' saving rates declines over time. The life cycle model is hence very successful in explaining the three stylized features found in the data.

Yet, there are two dimensions along which the model's performance could be better. First, the predicted initial saving rate differences are smaller than in the data for most of the cohorts, except for the oldest ones. While in the data the initial difference lies at around 2 percentage points for younger cohorts, and around 4 percentage points for cohorts that are 40 or older at reunification, the predicted differences are smaller than 2 percentage points for the younger cohorts, and only reach 4 percentage points for the cohorts that are older than 50 at reunification. Section 5.3.1 shows that the performance of the model in terms of matching the East-West saving rate differences quantitatively improves if one allows for expectations deviating from realizations. Second, for the youngest cohorts, the model predicts an increase in the saving rate differences for the first years,

\footnotetext{
${ }^{42}$ The bumpiness of the lines is solely a consequence of the limited smoothing of the demographic inputs.
} 


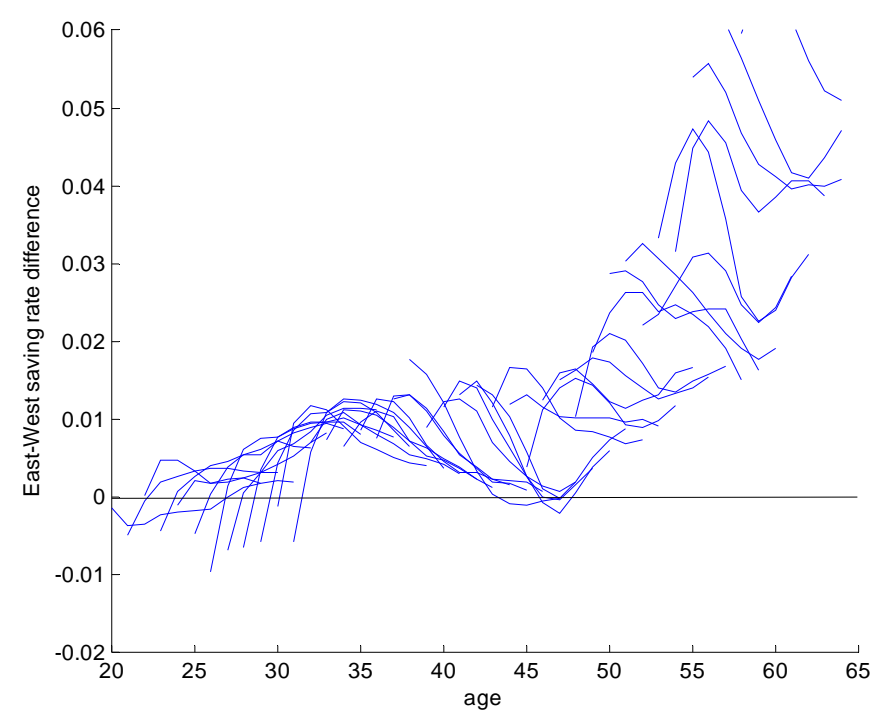

Figure 9: East-West saving rate differences in baseline calibration.

before the differences start to decline. This result of the model is discussed in detail in Section 5.2 .2 .

Why is the model able to replicate the major features of the data? First, the positive saving rate difference between East and West Germans arises due to the low wealth holdings of East Germans at reunification. An East German household who faces a similar economic environment as a West German household of the same age from 1992 on, but is endowed with much lower wealth holdings in 1992, saves more than the corresponding West German household to at least partly make up for this wealth difference. This is true under any saving motive, as long as West Germans accumulate positive wealth holdings optimally from the beginning of the life cycle on. Importantly, the initial East-West wealth ratio is smaller than the income ratio for every cohort, indicating that the wealth holdings of the East German households are sub-optimal in the context 
of the new economic environment.

Second, the initial East-West saving rate difference is larger for older cohorts since the relative wealth holdings of East households at reunification are smaller for older cohorts. Thus, the effect explained above is especially large for the older cohorts. Moreover, older East German households have less time left over their working life to increase their wealth holdings.

Since the positive saving rate difference, as well as the increase in the saving rate difference by birth cohort, are mostly driven by the initial wealth holdings of East and West Germans, these features are quite robust to the exact specification of the model, as Section 5.2 will show. On the contrary, the decline in the saving rate differences over time is essentially tied to the precautionary saving motive. For this reason, I discuss the intuition for this third feature in Section 5.2.1.

Note that the initial saving rate differences would be larger in the absence of convergence of East incomes in the early 1990s. The higher income growth of East Germans between 1992 and 1997 decreases their relative incentives to save. In line with the estimation results, the simulation results therefore actually show that the saving rate differences often still increase slightly between 1992 and 1993, before starting their much more pronounced decline.

Assuming that there is no variance in the wealth holdings of East Germans of a certain birth cohort in 1992 would lead to slightly smaller predicted initial saving rate differences. The reason lies in the concavity of the consumption function (see Figure 7). Due to the concavity, a meanpreserving spread in the initial wealth holdings of East Germans leads to lower initial consumption. However, even going to the extreme of assuming zero variance in the distribution of wealth holdings within a cohort in 1992, the results change only slightly. ${ }^{43}$

\footnotetext{
${ }^{43}$ Note that in the 1993 round of the EVS, the within age group standard deviation of total wealth holdings in the
} 


\subsection{The Importance of Different Saving Motives}

The analysis so far has shown that a comprehensive life cycle model is able to explain the saving behavior of East and West Germans after reunification. To analyze the relative importance of different saving motives in explaining the features in the data, I shut down the motives one by one and derive the predicted features of the model without the specific motive. The three components that are most interesting are the precautionary saving component, demographics, and retirement. ${ }^{44}$ Following the procedure used in the baseline analysis, in each case East Germans enter the economy in 1992, and are endowed with the estimated shares of the simulated wealth holdings of West Germans of the corresponding age in the respective model.

\subsubsection{Precautionary Saving}

To analyze the importance of the precautionary saving motive, I solve the model with a deterministic income process, and without imposing a liquidity constraint. ${ }^{45}$ Figure 10 shows the resulting predictions for the East-West saving rate difference. Note the different scale in contrast to Figures 3 and 9 . Without the precautionary saving motive, the life cycle model cannot replicate any of the three stylized facts. First, the predicted saving rate difference is negative for all cohorts. Thus, East Germans save less than West Germans in this specification. This is the case because the positive life cycle income growth coupled with impatience induces West Germans to accumulate

East is on average $54 \%$ of the standard deviation of the same age group in the West. Yet, since East and West are based on current residence here, the estimated standard deviation is probably larger in the West sample than if one would identify households by their residence before reunification.

${ }^{44}$ Shutting down mortality risk has only negligible effects once the time discount factor is recalibrated to still match the consumption hump.

${ }^{45} \mathrm{~A}$ deterministic income process in conjunction with a liquidity constraint leads to zero saving for most of the working life, until households accumulate some wealth close to retirement. Thus, the predicted saving rate difference would also be zero except for the older cohorts. The other possible assumption, namely a stochastic income process without the liquidity constraint, leads to qualitatively similar results as the case discussed in the text. 


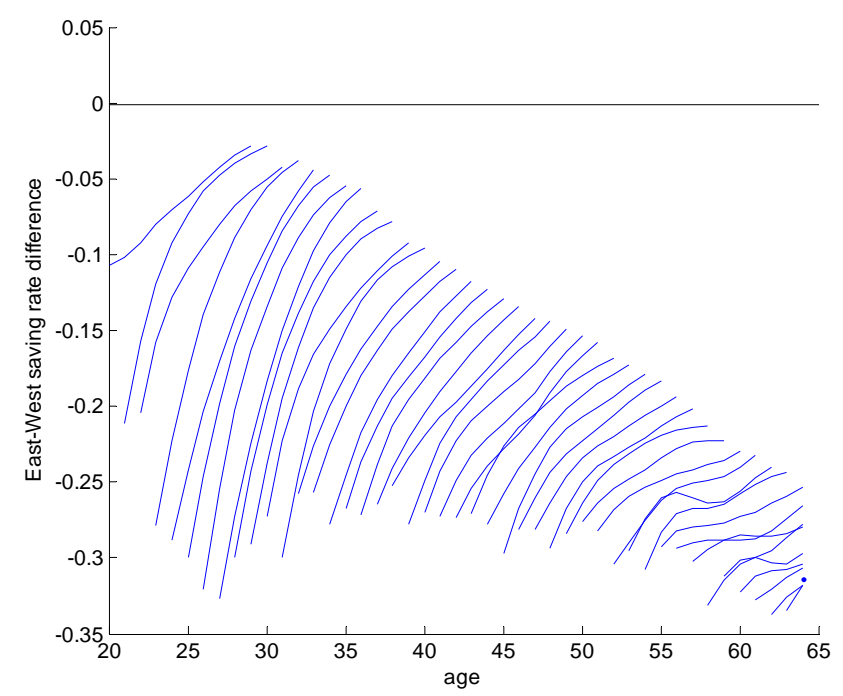

Figure 10: East-West saving rate differences in calibration abstracting from income risk and liquidity constraint.

debt in the first 30 periods of their working life. Only after that do they start to save for retirement, but without reaching positive wealth holdings on average. As a consequence, the estimated wealth holdings of East Germans at reunification are actually less negative than the ones of West Germans, making East Germans relatively better off in terms of total net worth despite their lower future income, and thus turning the saving rate differences negative. Second, the saving rate difference is not larger for older cohorts, since especially the West households aged 40 to 65 have accumulated large amounts of debt. Therefore, especially for these birth cohorts are households from the East better off with regard to their wealth holdings in 1992 than households from the West.

Yet, these are not the most interesting failures of the model without precautionary savings, since they arise quite mechanically due to the absence of a liquidity constraint. Assuming higher patience, one could induce West Germans to save from the start of the life cycle on, turning the saving rate 
differences positive again, and restoring the cohort ordering. More importantly, instead of predicting a decline in the East-West saving rate difference over time, the model predicts an increase for all cohorts. ${ }^{46}$ This increase is caused by a combination of the effects of demographics (see Section 5.2.2), and the higher growth rates of East German incomes in the early 1990s. Thus, the precautionary saving motive is a necessary component of the life cycle model if one wants to explain the observed decline in the East-West saving rate differences after 1992. In the precautionary saving model, this decline arises because in this model the saving rate is a decreasing function of the difference between actual wealth holdings and the target level of wealth. Since East Germans' wealth holdings at reunification are far below their optimal buffer stock wealth holdings, they initially save a lot. As East Germans consequently successfully build up a buffer stock over time, their saving rates decline. Hence, this decline is very specific to the precautionary saving component of the model.

\subsubsection{Demographics}

Figure 11 shows the predictions of the model for the saving rate differences when household size is held constant throughout the life cycle. The predicted saving rate difference is now positive and declining also for the cohorts younger than 35 years in 1992. East German cohorts in this age group have relatively large household sizes in 1992 and only experience a slight increase in household size as they grow older, while for West German cohorts this is the age at which children primarily enter the household (see Figure 6). Thus, the initial saving rates of these households are relatively high in the West and declining over time as children enter the household, while East Germans are already closer to their peak in household size, and thus exhibit smaller saving rates. Abstracting from these

\footnotetext{
${ }^{46}$ Note that this remains true even if one would increase patience in order to turn the East-West saving rate difference positive.
} 
demographic effects, the predicted saving rate differences of these generations match the empirical ones much better.

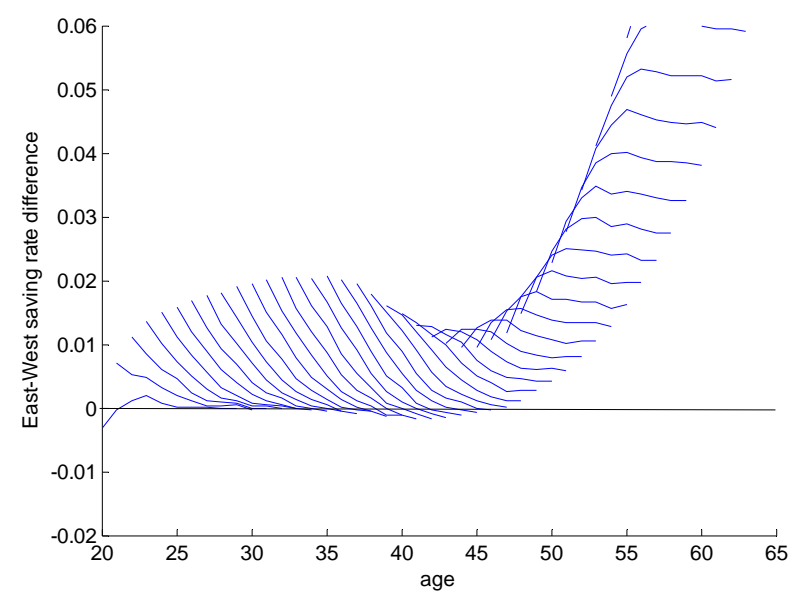

Figure 11: East-West saving rate differences in calibration abstracting from demographics.

Only the convergence of the saving rate differences of the oldest cohorts who are very close to retirement was more pronounced when demographics were taken into account. As Figure 6 shows, while household size is declining for West German households around the age of 55 to 65 , this decline is less pronounced for these households in the East (in fact, for some cohorts household size is still slightly increasing). This can explain why saving rates of West Germans of this age group are increasing faster than the ones of East Germans, which leads to a narrowing of the saving rate difference. Hence, the decrease in the East-West difference of saving rates for the oldest cohorts observed in the baseline calibration is due to the combined effects of demographics and precautionary savings.

Consequently, the calibration of adult equivalences is important for the performance of the model. Note that alternative estimates of adult equivalence scales for West Germany as derived 
from a semi-parametric estimation on EVS data by Wilke (2006) generally propose lower adult equivalences, thereby improving the performance of the model. ${ }^{47}$ The fact that the comprehensive model with demographics has more difficulties in explaining the East-West saving rate differences could mean one of three things. First, East Germans' expectations about the development of household sizes might have differed from the ex-post realization; second, East Germans might have misjudged the necessary change in consumption to hold household utility constant if household size changes, i.e. effectively misjudging adult equivalence scales; or third, adult equivalence scales in fact differed between East and West. If adult equivalence scales were for some reason lower in the East than in the West in the early 1990s, the performance of the model in matching the saving rate differences of the younger generations would improve. ${ }^{48}$

\subsubsection{Retirement}

I shut down the retirement period of the model by assuming that individuals die with probability one after 45 life cycle periods.

As Figure 12 shows, the predicted East-West saving rate differences without the retirement saving motive are qualitatively very similar to the ones in the baseline calibration. The initial differences are slightly larger for the middle-aged and older cohorts, thus improving the performance of the model somewhat. ${ }^{49}$ Moreover, the decrease in the difference over time is more pronounced for these cohorts. Therefore, I conclude that retirement savings decrease the performance of the model

\footnotetext{
${ }^{47}$ Wilke (2006) however only estimates adult equivalences for selected family sizes (namely up to two children). For this reason, I recur to the estimates by Faik and Merz (1995).

${ }^{48}$ This could e.g. be the case if child care was on average cheaper in the East than in the West in the early 1990 s. Certainly, child care availability was much higher in the East than in the West in that time period.

${ }^{49}$ The predicted initial saving rate differences lie between eight and ten percentage points for the oldest cohorts. For ease of comparison, I keep the scale of the graph as in previous figures.
} 


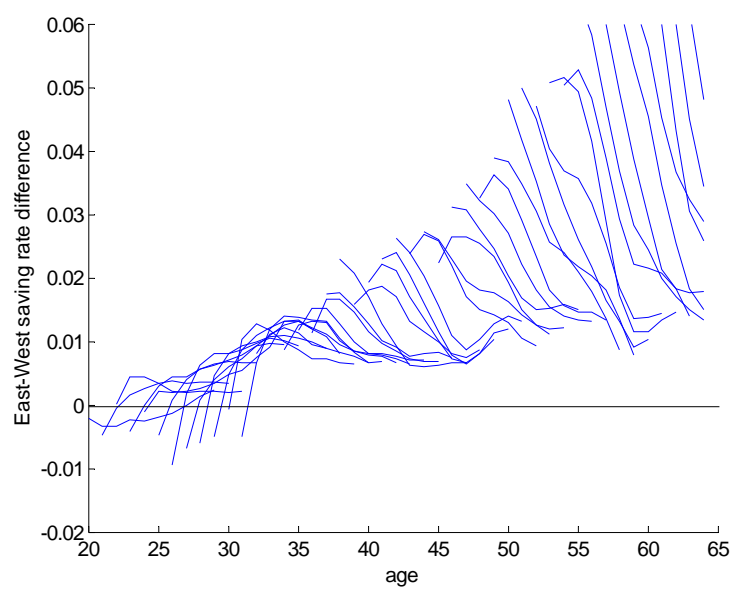

Figure 12: East-West saving rate differences in calibration abstracting from a retirement period.

somewhat in terms of matching observed East-West saving rate differences, but are nevertheless essential in explaining the level of wealth holdings and the hump in consumption observed in the data. The reason for the slightly less successful predictions of the East-West saving rate differences once retirement is taken into account lies in the fact that the consumption function is more concave at lower levels of cash at hand (see Figure 7). The first two empirical features are stronger the more concave the consumption function. Since retirement saving leads on average to higher wealth holdings, more households find themselves in regions where the consumption function is less concave.

\subsection{Robustness Checks on Income Expectations}

So far in this analysis, I assume that individuals' expectations about the income process are identical to the ex-post observed outcomes. The validity of this assumption is especially contentious when it comes to expectations about the future income paths of East Germans. Could East Germans in 1992 correctly predict the convergence process of incomes, as well as their riskiness? To gain insights into the importance of these assumptions, I show results from two robustness checks. Each 
time, the expectations about either the growth rate of income or the riskiness of income are modified when the model is solved, but the actual estimated income process is used when simulating the model. Thus, all changes result solely from changes in the policy functions due to modified income expectations.

\subsubsection{Income Risk Expectations}

Income risk comprises both the risk of unemployment, as well as the variability of wages conditional on being employed. Arguably, in the public perception unemployment risk looms larger. ${ }^{50}$ The unemployment rate was almost three times as large in East Germany as in West Germany in 1992 (15.4\% vs. $5.9 \%)$, and still more than twice as large in 2000 (17.4\% vs. $7.8 \%)$. Therefore, it is possible that East Germans perceived their income risk as higher than the income risk of West Germans, and vice versa. To analyze the consequences of such potential perceptions of income risk, I increase both the expected variances of the permanent and temporary shocks of East Germans to the upper end of the 95 percent confidence interval of the point estimates (i.e. by 1.96 times the estimated standard deviation), while I decrease both the expected variances of the permanent and temporary shocks of West Germans to the lower end of the 95 percent confidence interval (i.e. by 1.96 times the estimated standard deviation). As a result, the expected variances are $\sigma_{\epsilon}^{2}=0.0429$ and $\sigma_{\mu}^{2}=0.0137$ for East Germans, and $\sigma_{\epsilon}^{2}=0.0318$ and $\sigma_{\mu}^{2}=0.0097$ for West Germans.

Figure 13 shows the resulting East-West saving rate differences. The expectation of higher income risk induces East Germans to save more than in the baseline calibration, and the opposite holds true for West Germans. As a consequence, the East-West saving rate differences are generally

\footnotetext{
${ }^{50}$ For example, the official unemployment rate is announced monthly and regularly discussed in the media, while the general variability of wages is analyzed far less frequently, and attracts less attention in the media.
} 


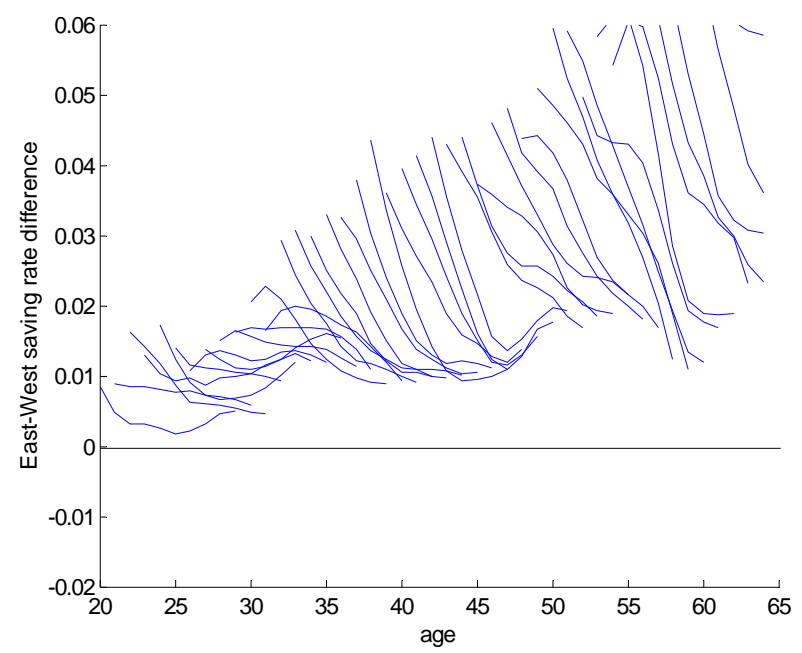

Figure 13: East-West saving rate differences in calibration assuming East expectations of higher income risk and West expectations of lower income risk.

larger. This improves the performance of the model in matching the observed magnitudes of the saving rate differences in the data. In fact, the predicted saving rate differences in 1992 under this calibration line up very well with the empirical ones, starting at around 1.5 percentage points for the younger cohorts, and reaching 4 percentage points at age 40 . Even for the cohorts between 25 and 30 years old in 1992, the model now predicts a relatively stable saving rate difference, rather than a pronounced increase in the difference over time.

\subsubsection{Expectations about Income Convergence}

While it seems reasonable to assume that East Germans might have expected higher income risk, it is less clear whether they expected even more dramatic income convergence than they experienced in the first half of the 1990s, or less income convergence. Figure 14 shows the predicted saving rate differences if East Germans had expected no further convergence of East incomes to West incomes in 1992. The relatively lower expectations of income growth for East Germans would have induced 


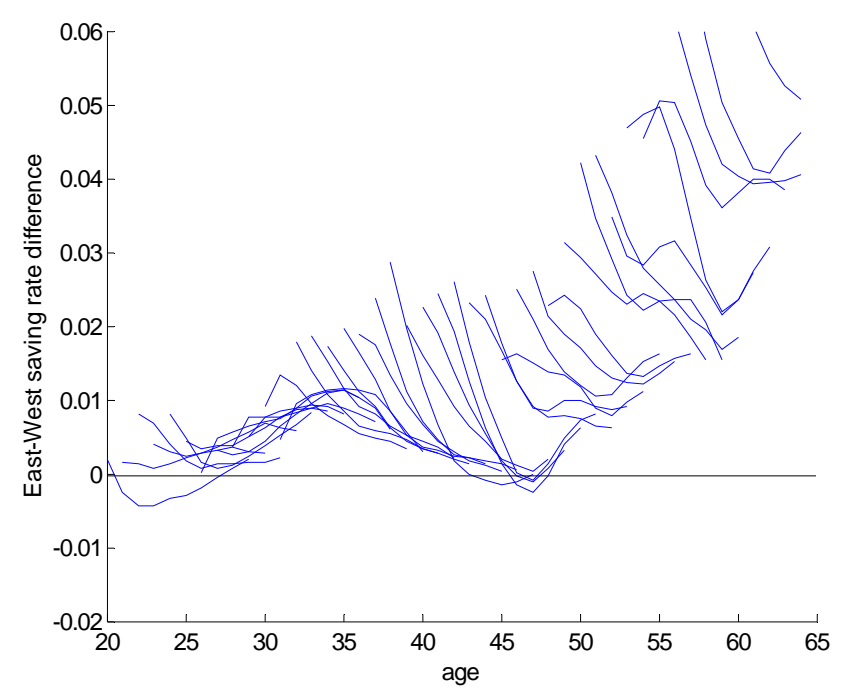

Figure 14: East-West saving rate differences in calibration assuming East expectations of no further income convergence.

them to save more than in the baseline calibration, resulting in an increase in the initial East-West saving rate differences. Thus, the overall performance of the model in matching the magnitudes of the data improves somewhat under this assumption. Of course, the opposite holds true as well: if East Germans assumed even more convergence of incomes than they experienced, the model would have predicted lower saving rate differences than in the baseline calibration.

\section{Conclusion}

The natural experiment of German reunification provides strong evidence in favor of the life cycle hypothesis. In the empirical analysis, I find that East Germans have higher saving rates than West Germans after reunification, that the East-West saving rate difference is larger for older cohorts, and that this difference is declining over time for every cohort. This saving behavior of East and 
West Germans after the large economic shock of German reunification fits the predictions of a standard comprehensive life cycle model very well. The model can replicate all three empirical features, both qualitatively and quantitatively. The quantitative match improves somewhat if one allows for a slight deviation of expectations of future income risk from the ex-post realization, motivated by the observed differences in unemployment rates between East and West.

The precautionary saving motive is essential for the success of the model. Without precautionary savings, the model fails to predict the decrease in the East-West saving rate differences of the 1990s. On the contrary, accounting for changing demographics over the life cycle decreases the performance of the model in matching the saving rate behavior of the younger generations. Arguably, if adult equivalence scales differed for East and West, the effects of demographics would change and could be more favorable for the model. Yet, estimating adult equivalence scales is beyond the scope of this paper. Last, while retirement saving slightly decreases the ability of the model to match the East-West saving rate features after reunification, it is nevertheless a necessary component of the life cycle model to explain the level of wealth accumulation and the hump in consumption.

The life cycle model used in this paper is a standard model, incorporating a retirement period, stochastic labor income, a liquidity constraint, demographics, and age-dependent survival probabilities. One of the many less standard features that the model does not incorporate is a habit formation motive. Under the assumption of internal habits, agents derive utility not only from consumption, but also from positive consumption changes. Facing substantial positive income growth after reunification, East Germans would thus have increased consumption more slowly in the presence of habits than without habits. Therefore, internal habits would provide an additional 
motive for East Germans to save right after reunification. ${ }^{51}$ Another possible explanation for the high saving rates of East Germans after reunification could be that East Germans were initially more risk averse or more patient than West Germans. ${ }^{52}$ This study cannot reject the possibility that these or other additional saving motives play a role in the saving behavior of East and West Germans. Yet, it shows that the standard features alone are enough to explain the saving behavior, thereby suggesting that any possible role of other motives is small.

Natural experiments have frequently been employed to analyze high frequency behavior of consumption, using quarterly, monthly or even daily data. Most of these studies focus on relatively small income changes, and find evidence against the permanent income hypothesis. ${ }^{53}$ One could interpret this failure as evidence that households are not forward looking in their consumption behavior, but rather follow simple rules of thumb. Notable exceptions to this result are found in studies which analyze large income changes that the consumer faces repeatedly over the life cycle. $^{54}$ This suggests that households might have to learn how to behave optimally. Moreover, if reoptimization after the arrival of news is associated with some fixed costs - psychological, monetary, or opportunity costs - then reoptimization might only be optimal for large income changes, and households might rather follow rules of thumb for small income changes (Hsieh 2003). This study

\footnotetext{
${ }^{51} \mathrm{~A}$ previous version of this paper, available from the author upon request, treats habit formation explicitly and employs an empirical test for habits, not finding any significant evidence for habits.

${ }^{52}$ Alesina and Fuchs-Schündeln (2007) provide evidence that Communism had a lasting impact on East Germans' preferences for a strong government.

${ }^{53}$ The studies typically find that, in contrast to the permanent income hypothesis, consumption growth changes significantly at preannounced income changes.

${ }^{54}$ I calculate the welfare losses associated with setting consumption equal to income in the respective experiments, assuming a time separable constant relative risk aversion utility function that is additive over monthly consumption with a risk aversion factor of 2, and a discount factor and gross interest rate of unity (see Browning and Crossley, 2001). Following are the calculated welfare losses for studies that find evidence against the permanent income hypothesis: Johnson, Parker and Souleles (2004): 0.2\%, Parker (1999): 0.6\%, Shapiro and Slemrod (1995): 0.05\%, Shea (1995): 0.01\%, Souleles (1999): 1.3\%, Souleles (2002): 0.01\%. For studies that do not find evidence against the permanent income hypothesis: Browning and Collado (2001): 7\%, Hsieh (2003): 3.4\%, and Souleles (2000): 2.1\%.
} 
- while analyzing the effects of an income shock, rather than a preannounced income change falls into the category of studies analyzing large changes, and clearly finds evidence in favor of rational consumption behavior. Reoptimization after reunification was optimal even if its costs, whether psychological or monetary, might have been large. Moreover, the natural experiment of German reunification provides evidence that repetition of income changes is not necessary to generate optimal behavior by households. 


\section{References}

[1] Alesina, Alberto and Nicola Fuchs-Schündeln (2007): Good Bye Lenin (or Not?): The Effect of Communism on People's Preferences, American Economic Review, 97(4), 1507-1528.

[2] Attanasio, Orazio, James Banks, Costas Meghir and Guglielmo Weber (1999): Humps and Bumps in Lifetime Consumption, Journal of Business and Economic Statistics, 17(1), 22-35.

[3] Attanasio, Orazio and Guglielmo Weber (1995): Is Consumption Growth Consistent with Intertemporal Optimization? Evidence from the Consumer Expenditure Survey, Journal of Political Economy, 103(6), 1121-1157.

[4] Biewen, Martin (2000): Income Inequality in Germany during the 1980s and 1990s, Review of Income and Wealth, 46(1), 1-19.

[5] Börsch-Supan, Axel, Anette Reil-Held, Ralf Rodepeter, Reinhold Schnabel and Joachim Winter (2001a): The German Savings Puzzle, Research in Economics, 55(1), 15-38.

[6] Börsch-Supan, Axel, Anette Reil-Held, Ralf Rodepeter, Reinhold Schnabel and Joachim Winter (2001b): Household Savings in Germany, in: Börsch-Supan, Axel (ed.): International Comparisons of Household Saving, Academic Press, New York.

[7] Börsch-Supan, Axel and Peter Schmidt (2001): Early Retirement in East and West Germany, in: Riphahn, Regina T., Dennis J. Snower and Klaus F. Zimmermann (eds.): Employment Policy in Transition. The Lessons of German Integration for the Labor Market, SpringerVerlag, Berlin.

[8] Bonin, Holger and Rob Euwals (2002): Participation Behavior of East German Women after German Reunification, William Davidson Working Paper 477, July 2002.

[9] Browning, Martin and M. Dolores Collado (2001): The Response of Expenditure to Anticipated Income Changes: Panel Data Estimates, American Economic Review, 91(30), 681-692.

[10] Browning, Martin and Thomas F. Crossley (2001): The Life-Cycle Model of Consumption and Saving, Journal of Economic Perspectives, 15(3), 3-22.

[11] Carroll, Christopher D. (1992): The Buffer-Stock Theory of Saving: Some Macroeconomic Evidence, Brookings Papers on Economic Activity, 2/1992, 61-135.

[12] Carroll, Christopher D. and Andrew A. Samwick (1997): The Nature of Precautionary Wealth, Journal of Monetary Economics, 40(1), 41-71.

[13] Carroll, Christopher D. and David N. Weil (1994): Saving and Growth: A Reinterpretation, Carnegie Rochester Conference Series on Public Policy, 40, 133-192.

[14] Faik, Jürgen and Joachim Merz (1995): Equivalence Scales Based on Revealed Preference Consumption Expenditures. The Case of Germany, Jahrbücher für Nationalökonomie und Statistik, 214(4), 425-447. 
[15] Fernández-Villaverde, Jesús and Dirk Krueger (2005): Consumption and Saving over the Life Cycle: How Important are Consumer Durables?, mimeo.

[16] Friedman, Milton (1957): A Theory of the Consumption Function, Princeton University Press, Princeton.

[17] Fuchs-Schündeln, Nicola and Matthias Schündeln (2005): Precautionary Savings and SelfSelection: Evidence from the German Reunification 'Experiment', Quarterly Journal of Economics, 120(3), 1085-1121.

[18] Gourinchas, Pierre-Olivier and Jonathan A. Parker (2002): Consumption over the Life Cycle, Econometrica, 70(1), 47-89.

[19] Gross, David B. and Nicholas S. Souleles (2002): Do Liquidity Constraints and Interest Rates Matter for Consumer Behavior? Evidence from Credit Card Data, Quarterly Journal of Economics, 117(1), 149-185.

[20] Heckman, James (1974): Life Cycle Consumption and Labor Supply: An Explanation of the Relationship Between Income and Consumption over the Life Cycle, American Economic Review, 64(1), 188-194.

[21] Hsieh, Chang-Tai (2003): Do Consumers React to Anticipated Income Changes? Evidence from the Alaska Permanent Fund, American Economic Review, 93(1), 397-405.

[22] Johnson, David, Jonathan Parker and Nicholas S. Souleles (2004): Household Expenditure and the Income Tax Rebates of 2001, American Economic Review, 96(5), 1589-1610.

[23] Levinsohn, James A. and Amil Petrin (2003): Estimating Production Functions Using Inputs to Control for Unobservables, Review of Economic Studies, 70(2), 317-341.

[24] Modigliani, Franco and Richard Brumberg (1954): Utility Analysis and the Consumption Function: An Interpretation of Cross-Section Data, in: Kurihara, Kenneth (ed.): Post-Keynesian Economics, Rutgers University Press, New Brunswick.

[25] Münnich, Margot (2001): Einkommens- und Geldvermögensverteilung privater Haushalte in Deutschland - Teil 2. Ergebnis der Einkommens- und Verbrauchsstichprobe 1998, in: Wirtschaft und Statistik, 2/2001, 121-137.

[26] OECD (2001): Economic Surveys: Germany, Paris.

[27] Parker, Jonathan A. (1999): The Reaction of Household Consumption to Predictable Changes in Payroll Tax Rates, American Economic Review, 89(4), 959-973.

[28] Shapiro, Matthew D. and Joel Slemrod (1995): Consumer Response to the Timing of Income: Evidence from a Change in Tax Withholding, American Economic Review, 85(1), 274-283.

[29] Shea, John (1995): Union Contracts and the Life-Cycle/Permanent-Income Hypothesis, American Economic Review, 85(1), 186-200. 
[30] Sinn, Hans-Werner (2002): Germany's Economic Unification: An Assessment after Ten Years, Review of International Economics, 10(1), 113-128.

[31] Sinn, Gerline and Hans-Werner Sinn (1991): Kaltstart. Volkswirtschaftliche Aspekte der deutschen Vereinigung, J.C.B. Mohr (Paul Siebeck), Tübingen.

[32] SOEP Group (2001): The German Socio-Economic Panel (GSOEP) after more than 15 years - Overview, in: Elke Holst, Dean R. Lillard und Thomas A. DiPrete (ed.): Proceedings of the 2000 Fourth International Conference of German Socio-Economic Panel Study Users (GSOEP 2000), Vierteljahrshefte zur Wirtschaftsforschung, 70(1), 7-14.

[33] Souleles, Nicholas S. (2002): Consumer Response to the Reagan Tax Cuts, Journal of Public Economics, 85(1), 99-120.

[34] Souleles, Nicholas S. (2000): College tuition and household savings and consumption, Journal of Public Economics, 77(2), 185-207.

[35] Souleles, Nicholas S. (1999): The Response of Household Consumption to Income Tax Refunds, American Economic Review, 89(4), 947-958.

[36] Thurow, Lester C. (1969): The Optimum Lifetime Distribution of Consumption Expenditures, American Economic Review, 59(3), 324-330.

[37] Wilke, Ralf A. (2006): Semiparametric Estimation of Consumption Based Equivalence Scales - The Case of Germany, Journal of Applied Econometrics, 21(6), 781-802. 


\section{Appendix}

\section{A Construction of Saving Rate}

\section{A.1 Financial Saving}

Positive financial saving is identified by a direct question (see footnote 9). The question asks for the "usual" amount of saving left over at the end of the month. I interpret this as monthly saving averaged over one year. Thus, any fluctuations of saving rates within a year, e.g. seasonal fluctuations due to vacations or holidays, should not affect this measure. I cross-check the saving rate of positive financial saving over disposable income with the average saving rate given by the Bundesbank, and both are quite similar (see figure 15). Hence, I am confident that this measure consists of deposits into bank accounts of various kinds (including building societies), and purchases of stocks and bonds, similar to the definition of the Bundesbank. Correspondingly, negative financial saving would be defined as withdrawal from bank accounts, and sales of bonds and stocks. Yet, I do not have this information, and accordingly the saving measure is left-censored for those who report zero financial saving. Last, financial saving should also comprise amortization of, minus take-up of, consumer loans. Questions about consumer loans were only added in 1997 to GSOEP, and do not indicate the date and amount of a take-up, but only the sum of amortization and interest payments. Hence, I have to omit this category. ${ }^{55}$

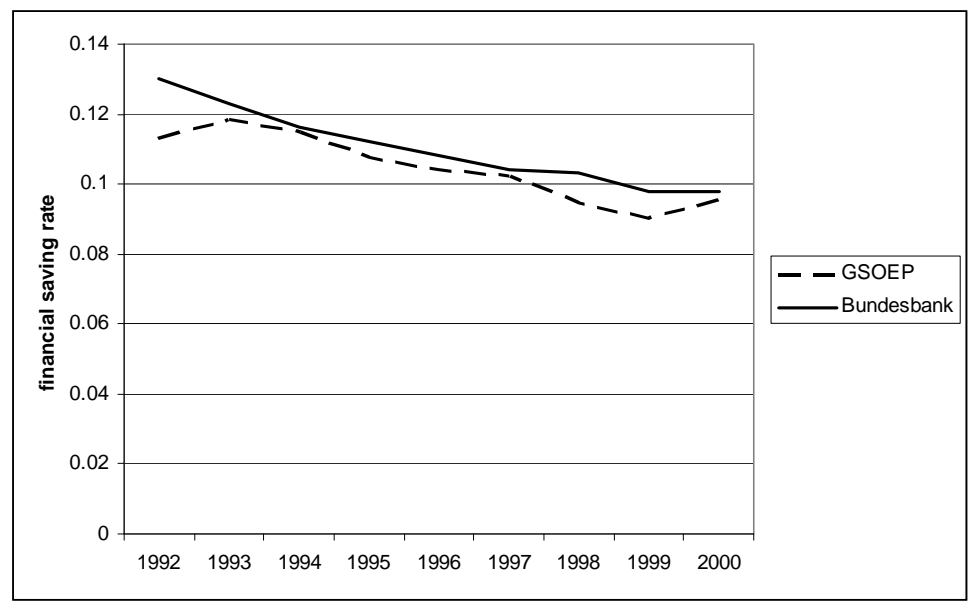

Figure 15: Average financial saving rate of German households, as provided by the Bundesbank and constructed from the GSOEP sample.

\footnotetext{
${ }^{55}$ Consumer loans play a relatively small role in Germany. The average stock of household consumer debt amounted to 2533 DM in 1998 (Münnich, 2001).
} 


\section{A.2 Real Saving}

Positive real saving consists of purchase of real estate and amortization of mortgages, while negative real saving comprises sale of real estate and take-up of a mortgage. I do not have information about sales prices of housing. This is not problematic under the assumption that the amount acquired by the sale of real estate flows into financial saving or new real saving rather than consumption, thereby leaving the sum of saving at zero. Moreover, since the purchase of a house must be financed by financial dissaving and/or the take-up of a mortgage, the sum of these three saving measures also results in zero saving. Hence, in net the amortization of mortgage is the real saving measure I am interested in. I also assume that expenditure for upkeep and improvement of housing equals the depreciation of the house, and hence both categories of real saving sum to zero.

To calculate the monthly amortization of a mortgage from the sum of interest and amortization payments, I make the following four assumptions. First, the borrower pays back the mortgage in constant annuity amounts. Second, the overall duration of the mortgage is 30 years, which is the average duration of mortgages in Germany (Eurohyp, 2002). Third, the interest rate on the mortgage is equal the average interest rate on 10 year fixed mortgages during the period 1971 to 2001, namely 8.25\% (Rheinische Hypo Frankfurt, 2002). Fourth, interest accrues yearly. From these four assumptions, I can calculate the percentage of observed annuity payments that is due to amortization, depending on the time elapsed since taking on the mortgage. At the beginning of the mortgage, amortization accounts for a very small part of the annuity payment, while at the end almost all the annuity payment constitutes amortization. I assume that the start year of the mortgage is the year in which the owner moved into the house. If a household indicates that it purchased the house it was previously renting, I take the year of the purchase as the year the mortgage was taken up. Given the year of the mortgage and the schedule of interest to amortization ratios, I can calculate the monthly amortization from the reported amount of the annuity. Only this amortization amount is counted as real saving.

For those cases in which the calculated start date of the mortgage is more than 30 years ago, I proceed as follows. If the maximum year of mortgage in the survey years is bigger than 40, I assume that the calculation of the start date of the mortgage was wrong. For these payments, I proceed as described below for amortization payments for properties that are not owner occupied. If the maximum year is smaller than 40, I assume that I have the right start date, and that all payments in years of mortgage bigger than 30 consist entirely of amortization, since in fact the interest amount is probably very small.

The survey also reports interest and amortization payments for properties that are not owner occupied. Unfortunately, it gives no hint as to when these properties were acquired, and hence I cannot determine the start year of the mortgage. I therefore assume that the ratio of interest to amortization in the annuity payment is equal to the median ratio of owner-occupied housing. 


\section{B Auxiliary Estimations for Calibration}

\section{B.1 Average Car Value in EVS}

EVS provides information on the number of used and newly purchased cars in the household. Moreover, it indicates the year of purchase as well as the purchase price, both within certain categories, for one used and one newly purchased car. Thus, I can construct an estimate of the car value of one newly purchased and one used car in the household. Only $5 \%$ of households own two or more newly purchased cars, and only $6.6 \%$ of households own two or more used cars. For these households, I assume that the second (and each additional) car is of average value of either newly purchased or used cars in the economy.

To get an estimate of the value of a car, I take the middle value of the price category that the household indicates as purchase price, and deflate this value based on the years passed since purchase. Deflation rates for personal cars come from a Swiss organization of professional car appraisers. I assume that a used car is three years old at the time of purchase. For households that purchased their car in the East before reunification, the purchase price is not given in EVS. I assume that such a car is worth DM 1500 in 1993. The resulting average values of cars in a household conditional on owning at least one car are 11,495 DM in the East, and 13,323 DM in the West.

\section{B.2 East Incomes}

To estimate the level differences between East and West incomes, I build cohort-specific East-West income ratios in $2000{ }^{56}$ For smoothing purposes, I then regress these ratios linearly on the birth year, and construct the predicted East-West income ratio in 2000 for every cohort.

The convergence process is assumed to be the same for all cohorts, in the sense that growth rates of East-West income ratios are constant across cohorts for every year. To calculate these growth rates, I first construct cohort-specific East-West income ratios for the years 1992 to 2000. For each of the 9 years I then calculate the average of the East-West income ratios across all cohorts. Last, I calculate the growth rates of these average East-West income ratios. The growth rates are declining, and approaching 0 in 1997, indicating that convergence stopped in 1997. I assume no further convergence for all future years. Starting with the cohort-specific predicted East-West income ratios in 2000, I apply the estimated growth rates of the ratios backward to get cohort-specific East-West income ratios for earlier years.

As mentioned in Section 4.2.2, I assume that the underlying life-cycle income growth path is the same for East Germans as for West Germans. This implies that East-West income ratios by birth cohorts are constant over time once the convergence process in the East has come to a halt in 1997. Figure 16 depicts the actual East-West income ratios by birth cohort from 1997 to 2000, as well as the linear prediction in 2000. While surely the panel dimension is very short, the figure provides some suggestive evidence that the assumption of a constant ratio per cohort over time, and thus

\footnotetext{
${ }^{56}$ Alternatively, I could have calculated the level differences for any year other than 2000. For the East, I group 5 adjacent birth cohorts together in a rolling fashion to increase cell sizes. The first birth cohort taken into consideration is 1935 , since for earlier cohorts the cell sizes are very small.
} 
of an identical life-cycle income growth path in East and West, is not unreasonable. Moreover, the East-West income ratios indeed seem to be linearly decreasing in the age of the cohort.

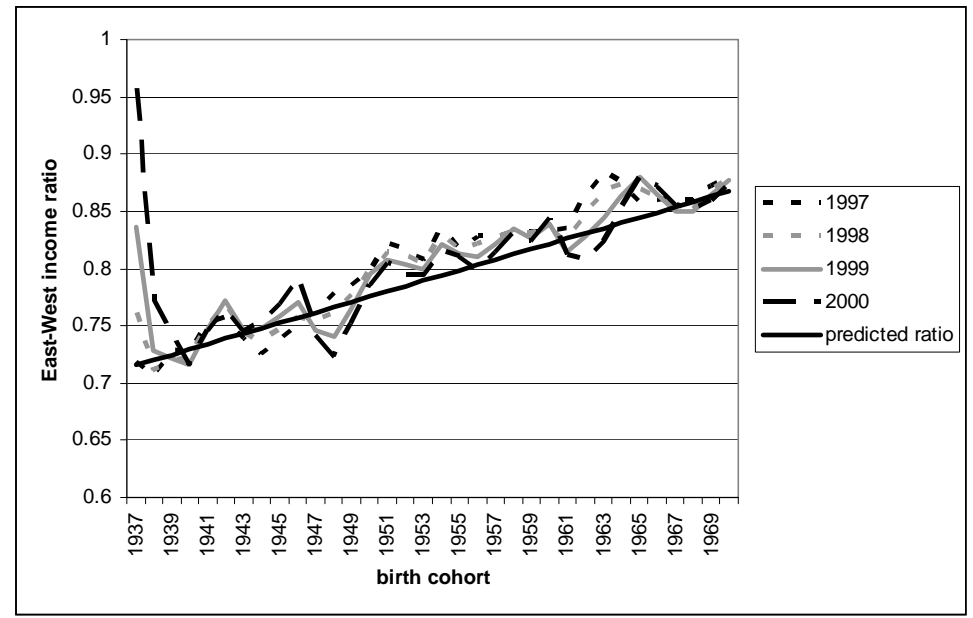

Figure 16: Actual and predicted East-West income ratios 1997 to 2000 by birth cohort

\section{B.3 Estimation of Income Risk}

Similar to Carroll and Samwick (1997), I remove the predictable component of income growth by dividing actual income through the predicted income value from a regression of the logarithm of income on a cubic function in age, education, occupation, family composition, and marital status, as well as interactions of age with education and occupation.

After removing the predictable income growth component $G_{t}$, one can write the income process in logarithms as $\widetilde{Y}_{t}=\widetilde{P}_{t}+\widetilde{\epsilon}_{t}$ and $\widetilde{P}_{t}=\widetilde{P}_{t-1}+\widetilde{\mu}_{t}$, where the tilda denotes the logarithm. One can then derive that $\operatorname{var}\left(\widetilde{Y}_{t+d}-\tilde{Y}_{t}\right)=d \sigma_{\mu}^{2}+2 \sigma_{\epsilon}^{2}$. I construct the unbiased estimate $v_{i d}$ of $\operatorname{var}\left(\tilde{Y}_{t+d}-\tilde{Y}_{t}\right)$ for household i as $v_{i, d}=\left(\widetilde{Y}_{i, t+d}-\widetilde{Y}_{i, t}\right)^{2}$ for all distances $d>2$. $\sigma_{\mu}^{2}$ and $\sigma_{\epsilon}^{2}$ are the resulting coefficients in the regression $v_{i, d}=d \sigma_{\mu}^{2}+2 \sigma_{\epsilon}^{2}+u_{i, d}$. By focusing on $d>2$, the estimates are consistent in the presence of serial correlation of the order $\mathrm{MA}(2)$ in $\epsilon_{t}$.

\section{B.4 Demographics}

Faik and Merz (1995) provide equivalence scales for different household compositions (single, single plus 1 child, single plus 2 children, married, married plus 1 child, up to married plus 4 children). They also provide equivalence scales simply based on household size. Whenever I cannot match the observed family composition to one of the specific ones they provide, I use these latter estimates. Whenever I observe 2 adults in a household, I assume that they are married.

I perform the following adjustment on the East data to control for the cohort effects in the West data: For every cohort-year group in the West, I calculate the difference between the observed 
average adult equivalences and the 2000 average adult equivalences of the same age group. I then subtract this amount from the respective cohort-year observation in the East. Thus, while clearly there is a major transition occurring in East household compositions from 1992 to 2000, part of this transition takes place similarly in the West, and I subtract this common component from the East data. I also have to make assumptions about the future trajectory of East German households. For the years 2001 and following, I assume that East German cohorts will have the same adult equivalences as the respective East age group in 2000.

Last, I smooth the data by running a locally weighted regression of the adult equivalences on age, with a fairly small bandwidth (using $20 \%$ of the observations), for every single cohort. This mechanism smoothes large year-to-year changes that are likely due to measurement error, but major trends, peaks etc. are matched very well. 